This item was submitted to Loughborough's Research Repository by the author.

Items in Figshare are protected by copyright, with all rights reserved, unless otherwise indicated.

\title{
A novel holistic EPC related retrofit approach for residential apartment building renovation in Norway
}

PLEASE CITE THE PUBLISHED VERSION

https://doi.org/10.1016/j.scs.2019.101975

PUBLISHER

Elsevier

VERSION

AM (Accepted Manuscript)

\section{PUBLISHER STATEMENT}

This paper was accepted for publication in the journal Sustainable Cities and Society and the definitive published version is available at

LICENCE

CC BY-NC-ND 4.0

\section{REPOSITORY RECORD}

Qu, Ke, Xiangjie Chen, Anandasivakumar Ekambaram, Yuanlong Cui, Guohui Gan, Andreas Okland, and Saffa Riffat. 2019. "A Novel Holistic EPC Related Retrofit Approach for Residential Apartment Building Renovation in Norway”. Loughborough University. https://hdl.handle.net/2134/13242470.v1. 


\section{Abstract}

4 This paper presents a novel Energy Performance Certification (EPC) related holistic building 5 retrofit approach for a Norwegian apartment block built in 1980s. Based on the pre6 combination principles of "Fabric priority", "Renewable in supplement", "Avoid complicated 7 installation", 11 energy retrofit measures (ERMs) were defined and combined into 18 typical 8 retrofit combination packages $(\mathrm{COMBs})$. Targeted simulations with the aim to explore the 9 interconnected and coupled impacts of selected ERMs are performed in a dynamic simulation tool IES Virtual Environment (VE). A novel Energy Limiting Difference (ELD) assessment factor has been defined, which only considers the difference between primary and renewable energy consumption in the extreme cold winter and hot summer months. The post retrofit EPC standard for each COMBs are then linked with these ELD assessment factors respectively. The relationship between ELD assessment factors and the relevant EPC grades for the 18 COMBs is plotted and verified against the obtained EPC results. Without performing the simulation for each month in conventional retrofit approaches, this approach leads to at least $78 \%$ reduced simulation efforts. This ELD-EPC related approach could therefore be used as useful guidelines for similar apartment building retrofits incorporating renewable energy measures in highdensity areas in the cold climate region.

Keywords: apartment building retrofit; energy retrofit measures; combination packages; building energy simulation; renewable energy

Abbreviation and acronyms

\begin{tabular}{|l|l|}
\hline ACH & Hourly Air Change Rate \\
\hline AI & Attic floor Insulation \\
\hline BIPV & Building Integrated Photovoltaic \\
\hline COMB & Combination Package \\
\hline COP & Coefficient of Performance \\
\hline DHW & Domestic Hot Water \\
\hline
\end{tabular}




\begin{tabular}{|l|l|}
\hline ED & Efficient Lighting device \\
\hline EPBD & Energy Performance of Building Directive \\
\hline ERM & Energy Retrofit Measures \\
\hline EPC & Energy Performance Certification \\
\hline ELD & Energy Limiting Difference \\
\hline EER & Energy Efficient Rate \\
\hline GR & Triple Glazing Retrofit \\
\hline GI & Garage Celling Insulation \\
\hline GSHP & Ground Source Heat Pump \\
\hline HVAC & Heating, Ventilation and Air Conditioning \\
\hline HR & Heat Recovery \\
\hline IES VE & $\begin{array}{l}\text { Integrated Energy Simulation and Virtual } \\
\text { Environment }\end{array}$ \\
\hline LED & Light-emitting diode \\
\hline PE & Primary Energy \\
\hline RE & Renewable Energy \\
\hline SP & Temperature Set Point Sensor \\
\hline ST & Flat Solar Thermal Collector \\
\hline
\end{tabular}

\section{Introduction}

24 The global average surface temperature has risen about $1.1^{\circ} \mathrm{C}$ since the late 19 th century, a change driven largely by the increased carbon dioxide and other human-related emissions into the atmosphere ("Global Climate Change Indicators," 2016). The European Commission has set up climate strategies with the aim to reduce greenhouse gas emissions by $40 \%$ and $80 \%$ respectively towards 2030 and 2050 in comparison to 1990 levels (EUROPEAN COMMISSION, 2011). The increasingly serious energy crisis and the demand for improving building indoor environmental quality and comfort levels have triggered great incentives for accelerating the development of energy efficient and innovative building technologies in the built environment sector.

Buildings are long-term assets which can have a life span of more than 50 years and $75-90 \%$ of those standing today are expected to remain in use in 2050 (EUROPEAN COMMISSION, 2016). However, in Europe, the building retrofits are carried out at low demolition rates $(0.1 \%$ per year) and low retrofit rates (1.2\% per year) (EUROPEAN COMMISSION, 2010). Most of

37 the existing buildings in Europe are not energy efficient (Ma, Cooper, Daly, \& Ledo, 2012;

38 Rabani, Madessa, \& Nord, 2017; Webb, 2017). According to Broin et al. (Ó Broin, Mata, 
Göransson, \& Johnsson, 2013; Project, January 2013), buildings in Europe consume about 40\% of the total European energy usage and contribute to almost $36 \%$ of greenhouse gases. In order to comply with the Kyoto Protocol goals and help to decarbonize the European economy, the Energy Performance of Building Directive (EPBD) was established in 2002 (EUROPEAN COMMISSION, 2002) and updated in 2010 (EUROPEAN COMMISSION, 2010), setting strict targets to building sector with the estimated $40 \%$ greenhouse gases reduction by 2030 . In order to achieve such energy target, the EU needs to boost the number of deep retrofits and to speed up the retrofit rate of the existing stock to above $2 \%$ annually (EUROPEAN COMMISSION, 2010). Within this context, many retrofit measures have been made to existing buildings with the aim to reduce energy consumption (Chen, Yang, \& Sun, 2016; Paiho, Seppä, \& Jimenez, 2015; Tadeu, Rodrigues, Tadeu, Freire, \& Simões, 2015), improve indoor thermal comfort and air quality (Psomas, Heiselberg, Duer, \& Bjørn, 2016) and move towards Low or Zero Energy Buildings (Desideri et al., 2013; Kylili \& Fokaides, 2015). Comprehensive reviews on building retrofit have been presented by Ma et al. (Ma et al., 2012), Mazzarela (Mazzarella, 2015) and Serrano-Jimenez et al. (Serrano-Jimenez, Barrios-Padura, \& MolinaHuelva, 2017).

Table 1 summarises the previous studies on various ERMs and their energy saving potential, with all the ERMs classified into passive, active and renewable measures. It can be noted that the corresponding energy saving potentials depend on the retrofit level and the numbers and features of ERMs included. The following conclusions can be drawn from Table 1:

i) When only considering passive measures, $11 \%-45 \%$ of primary energy consumption can be reached, with glazing and air-tightness being the two crucial energy saving ERMs. The influence of wall insulation on the overall energy saving performance vary largely in different countries, due to differences in weather conditions and existing building conditions. 
ii) The combination of passive and active measures can achieve around $34 \%$ to $51 \%$ of overall energy consumption reduction. The most energy efficient passive measures are replacing the existing lights with LED lighting technologies, the upgrading of heat recovery system and the installation of room temperature sensors and controllers.

iii) The combination of renewable energy with passive and active measures can achieve primary energy consumption reduction in the range of $71 \%-89 \%$ (close to near zero energy buildings' standards), which meets the deep retrofit goals.

Since the building fabric related passive retrofit measures have been chosen as the most easily applied ERM in published literature, we summarize it as the $1^{\text {st }}$ principle of "Fabric Priority" when choosing the energy retrofit measures (ERMs). From the simulation procedure point of view, renewable energy measures can serve as a supplement to "Fabric Priority" and further reduce the building primary energy load. This can be concluded as the $2^{\text {nd }}$ principle of "Renewable in supplement". Moreover, according to previous literature and surveys (Balcombe, Rigby, \& Azapagic, 2013; Baumhof, Decker, Röder, \& Menrad, 2018; Martek et al., 2019; Menassa \& Baer, 2014; Mills \& Rosenfeld, 1996), it should be noted that some complicated retrofit ERMs (e.g., external wall insulation, pipe and roof replacement) would cause serious disturbance to residents live nearby. Therefore, the $3^{\text {rd }}$ principle of "Avoid complicated installation process" needs to be considered to save time and cost for the retrofit process. 


\begin{tabular}{|c|c|c|c|c|c|c|c|c|c|c|c|c|c|c|c|c|}
\hline \multirow{2}{*}{ Reference } & \multirow{2}{*}{$\begin{array}{l}\text { Building } \\
\text { type }\end{array}$} & \multirow{2}{*}{\begin{tabular}{|c|} 
Location, \\
construction \\
year
\end{tabular}} & \multicolumn{4}{|c|}{ Passive Measures } & \multicolumn{4}{|c|}{ Active Measures } & \multicolumn{3}{|c|}{$\begin{array}{l}\text { Renewable } \\
\text { Measures }\end{array}$} & \multirow{2}{*}{$\begin{array}{c}\text { Pre-retrofit } \\
\text { baseline energy } \\
\text { consumption }\end{array}$} & \multirow{2}{*}{$\begin{array}{l}\text { Post-retrofit } \\
\text { energy } \\
\text { consumption }\end{array}$} & \multirow{2}{*}{ Conclusions } \\
\hline & & & EWI & RI & GR & $\mathrm{AT}$ & ED & TSCV & MVHR & EE & PV & $\mathrm{SC}$ & HP & & & \\
\hline \begin{tabular}{|c|} 
Casquero- \\
Modrego et \\
al. \\
(Casquero- \\
Modrego \& \\
Goñi- \\
Modrego, \\
2018) \\
\end{tabular} & $\begin{array}{c}\text { Apartment } \\
\text { building }\end{array}$ & Spain, 1964 & $\sqrt{ }$ & $\sqrt{ }$ & N/A & N/A & \multicolumn{4}{|c|}{ N/A } & \multicolumn{3}{|c|}{ N/A } & $\begin{array}{c}37 \mathrm{kWh} / \\
\mathrm{m}^{2} \text { thermal } \\
\text { energy } \\
\text { consumption in } \\
\text { winter }\end{array}$ & $\begin{array}{l}33 \mathrm{kWh} / \mathrm{m}^{2} \\
\text { thermal } \\
\text { energy } \\
\text { consumption } \\
\text { in winter } \\
(11 \% \\
\text { reduction) }\end{array}$ & $\begin{array}{c}\text { Envelope retrofit can improve } \\
\text { the thermal comfort and the } \\
\text { energy savings. }\end{array}$ \\
\hline $\begin{array}{c}\text { Fan et al. } \\
\text { (Fan \& Xia, } \\
\text { 2018) }\end{array}$ & $\begin{array}{c}\text { Office } \\
\text { building }\end{array}$ & $\begin{array}{c}\text { South } \\
\text { Africa, N/A }\end{array}$ & $\sqrt{ }$ & $\sqrt{ }$ & $\sqrt{ }$ & N/A & $\sqrt{ }$ & N/A & N/A & N/A & $\sqrt{ }$ & N/A & $\sqrt{ }$ & EPC grade E & EPC grade A & $\begin{array}{l}\text { HVAC, PV, building envelope } \\
\text { upgrading and the roof retrofit } \\
\text { have large energy saving } \\
\text { potential. }\end{array}$ \\
\hline \begin{tabular}{|c|} 
Cascio et al. \\
(Cascio, Ma, \\
Borelli, \& \\
Schenone, \\
2017)
\end{tabular} & $\begin{array}{c}\text { Apartment } \\
\text { building }\end{array}$ & $\begin{array}{l}\text { Australia, } \\
2006\end{array}$ & N/A & $\sqrt{ }$ & $\sqrt{ }$ & $\sqrt{ }$ & $\sqrt{ }$ & N/A & N/A & N/A & N/A & $\sqrt{ }$ & N/A & $103 \mathrm{kWh} / \mathrm{m}^{2}$ & $\begin{array}{l}11 \mathrm{kWh} / \\
\mathrm{m}^{2}(89 \% \\
\text { reduction })\end{array}$ & $\begin{array}{l}\text { Air tightness improvement and } \\
\text { LEDs upgrading are cost- } \\
\text { effective retrofit options. }\end{array}$ \\
\hline $\begin{array}{c}\text { Berardi et al. } \\
\text { (Berardi, } \\
\text { 2018) }\end{array}$ & $\begin{array}{c}\text { Educationa } \\
1 \text { office } \\
\text { building }\end{array}$ & $\begin{array}{c}\text { Canada, } \\
1931\end{array}$ & & N/A & $\sqrt{ }$ & N/A & $\sqrt{ }$ & N/A & N/A & N/A & & N/A & & $266 \mathrm{kWh} / \mathrm{m}^{2}$ & NA & $\begin{array}{c}\text { Upgrading the building } \\
\text { envelope with super-insulating } \\
\text { materials poses large energy } \\
\text { saving potential. }\end{array}$ \\
\hline $\begin{array}{l}\text { Liu et al. } \\
\text { (Liu, Liu, } \\
\text { Ye, \& Liu, } \\
\text { 2018) }\end{array}$ & $\begin{array}{c}\text { Apartment } \\
\text { building }\end{array}$ & China, 1988 & $\sqrt{ }$ & $\sqrt{ }$ & $\sqrt{ }$ & N/A & N/A & $\sqrt{ }$ & N/A & N/A & & N/A & & $\begin{array}{c}408,253 \mathrm{~m}^{3} \text { for } \\
\text { natural gas, } \\
144,150 \mathrm{kWh} \\
\text { for electricity }\end{array}$ & $\begin{array}{c}357,798 \mathrm{~m}^{3} \\
\text { for natural } \\
\text { gas, } \\
94,740 \mathrm{kWh} \\
\text { for electricity } \\
\text { (34\% } \\
\text { reduction) }\end{array}$ & $\begin{array}{l}\text { Replacing windows with } \\
\text { appropriate materials is a better } \\
\text { option than external wall } \\
\text { insulation from an economic } \\
\text { perspective. }\end{array}$ \\
\hline
\end{tabular}




\begin{tabular}{|c|c|c|c|c|c|c|c|c|c|c|c|c|c|c|c|c|}
\hline \begin{tabular}{|c|} 
Mora et al. \\
(Mora, \\
Cappelletti, \\
Peron, \\
Romagnoni, \\
\& Bauman, \\
2015) \\
\end{tabular} & $\begin{array}{c}\text { Apartment } \\
\text { building }\end{array}$ & Italy, 1923 & $\sqrt{ }$ & N/A & $\sqrt{ }$ & N/A & N/A & N/A & $\sqrt{ }$ & N/A & $\sqrt{ }$ & N/A & $\sqrt{ }$ & $342.1 \mathrm{kWh} / \mathrm{m}^{2}$ & $\begin{array}{c}95.9 \mathrm{kWh} / \\
\mathrm{m}^{2}(72 \% \\
\text { reduction })\end{array}$ & $\begin{array}{c}\text { Solar and photovoltaic system } \\
\text { contributed greatly to } \\
\text { minimizing energy } \\
\text { consumption. }\end{array}$ \\
\hline \begin{tabular}{|c} 
Dahlhausen \\
et al. \\
(Dahlhausen \\
, \\
Heidarinejad \\
\& Srebric, \\
2015)
\end{tabular} & $\begin{array}{l}\text { Commercia } \\
1 \text { office } \\
\text { building }\end{array}$ & $\begin{array}{c}\text { United } \\
\text { States, N/A }\end{array}$ & $\sqrt{ }$ & N/A & $\sqrt{ }$ & $\sqrt{ }$ & $\sqrt{ }$ & $\sqrt{ }$ & N/A & N/A & & N/A & & $313 \mathrm{kWh} / \mathrm{m}^{2}$ & $\begin{array}{l}189 \mathrm{kWh} / \\
\mathrm{m}^{2}(40 \% \\
\text { reduction })\end{array}$ & $\begin{array}{l}\text { Ambitious energy saving } \\
\text { targets require the installation } \\
\text { of a large number of building } \\
\text { components and heating and } \\
\text { cooling equipment }\end{array}$ \\
\hline \begin{tabular}{|} 
Jradi et al. \\
(M. Jradi, \\
Veje, \& \\
Jørgensen, \\
2018)
\end{tabular} & $\begin{array}{c}\text { Educationa } \\
1 \text { office } \\
\text { building }\end{array}$ & $\begin{array}{c}\text { Denmark, } \\
1930 \mathrm{~s}\end{array}$ & $\sqrt{ }$ & $\sqrt{ } \mathrm{I}$ & N/A & $\sqrt{ }$ & $\sqrt{ }$ & N/A & $\sqrt{ }$ & $\sqrt{ }$ & $\sqrt{ }$ & N/A & N/A & $191 \mathrm{kWh} / \mathrm{m}^{2}$ & $\begin{array}{c}55 \mathrm{kWh} / \mathrm{m}^{2} \\
(71 \% \\
\text { reduction })\end{array}$ & $\begin{array}{l}\text { A deep energy retrofit package } \\
\text { is recommended considering } \\
\text { upgrading the building } \\
\text { envelope along with the energy } \\
\text { supply systems. }\end{array}$ \\
\hline \begin{tabular}{|} 
Mauri et al. \\
(Mauri, \\
Vallati, \& \\
Ocłoń, \\
2019) \\
\end{tabular} & $\begin{array}{c}\text { Apartment } \\
\text { building }\end{array}$ & Italy, 2006 & $\sqrt{ }$ & N/A & $\sqrt{ }$ & N/A & N/A & $\sqrt{ }$ & N/A & N/A & & N/A & & $\begin{array}{c}39.5 \mathrm{kWh} / \mathrm{m}^{2} \\
\text { for space heating }\end{array}$ & $\begin{array}{c}22.1 \mathrm{kWh} / \\
\mathrm{m}^{2} \text { for space } \\
\text { heating }(44 \% \\
\text { reduction })\end{array}$ & $\begin{array}{l}\text { The interaction between user's } \\
\text { behaviour and technical } \\
\text { management plays a key role in } \\
\text { energy reduction and thermal } \\
\text { comfort optimization. }\end{array}$ \\
\hline $\begin{array}{c}\text { Carlsson et } \\
\text { al. } \\
\text { (Carlsson, } \\
\text { Touchie, \& } \\
\text { Richman, } \\
\text { 2017) }\end{array}$ & $\begin{array}{c}\text { Apartment } \\
\text { building }\end{array}$ & $\begin{array}{c}\text { Canada, } \\
\text { 1990s }\end{array}$ & N/A & N/Al & N/A & $\sqrt{ }$ & N/A & N/A & $\sqrt{ }$ & N/A & & N/A & & $\begin{array}{c}95 \mathrm{kWh} / \mathrm{m}^{2} \text { for } \\
\text { space heating }\end{array}$ & $\begin{array}{c}46 \mathrm{kWh} / \mathrm{m}^{2} \\
\text { for space } \\
\text { heating }(51 \% \\
\text { reduction })\end{array}$ & $\begin{array}{c}\text { Air-tightness and ventilation } \\
\text { behaviours have large impacts } \\
\text { on the overall energy } \\
\text { consumption in cold climates. } \\
\text { A heat recovery ventilation } \\
\text { system is recommended in cold } \\
\text { area. }\end{array}$ \\
\hline
\end{tabular}




\begin{tabular}{|c|c|c|c|c|c|c|c|c|c|c|c|c|c|c|c|c|}
\hline \begin{tabular}{|c|} 
Charles et al. \\
(Charles, \\
Maref, \& \\
Ouellet- \\
Plamondon, \\
2019) \\
\end{tabular} & $\begin{array}{c}\text { Office } \\
\text { building }\end{array}$ & $\begin{array}{c}\text { Canada } \\
1960 \mathrm{~s}\end{array}$ & $\sqrt{ }$ & N/AI & N/A & $\sqrt{ }$ & N/A & N/A & $\sqrt{ }$ & $\sqrt{ }$ & $\sqrt{ }$ & $\sqrt{ }$ & N/A & $252 \mathrm{kWh} / \mathrm{m}^{2}$ & $\begin{array}{c}139 \mathrm{kWh} / \\
\mathrm{m}^{2}(45 \% \\
\text { reduction) }\end{array}$ & $\begin{array}{l}\text { Envelope upgrading are one of } \\
\text { the most important parameters } \\
\text { in reducing of the building } \\
\text { energy consumption. }\end{array}$ \\
\hline $\begin{array}{c}\text { Fregonara et } \\
\text { al. } \\
\text { (Fregonara, } \\
\text { Verso, Lisa, } \\
\text { \& Callegari, } \\
\text { 2017) }\end{array}$ & $\begin{array}{c}\text { Detached } \\
\text { residential } \\
\text { house }\end{array}$ & Italy, 1963 & $\sqrt{ }$ & N/A & $\sqrt{ }$ & N/A & N/A & N/A & $\sqrt{ }$ & N/A & $\sqrt{ }$ & $\sqrt{ }$ & N/A & $\begin{array}{l}118 \mathrm{kWh} / \mathrm{m}^{2} \\
\text { EPC grade E }\end{array}$ & $\begin{array}{c}15.3 \mathrm{kWh} / \\
\mathrm{m}^{2}(87 \% \\
\text { reduction }) \\
\text { EPC grade A }\end{array}$ & $\begin{array}{l}\text { The best solution in terms of } \\
\text { energy saving does not } \\
\text { necessarily accommodate the } \\
\text { retrofitting costs saving } \\
\text { requirement. }\end{array}$ \\
\hline
\end{tabular}

85 EWI is the external wall insulation; RI is the roof insulation; GR is the glazing renovation; AT is the airtightness improvement; ED is the efficient 
Further observation of Table 1 reveals that previous research hardly investigated the alternative combinations of various ERMs and their impacts on energy saving and carbon reductions. Moreover, since the impact of various ERMs on the primary energy consumption reductions are interconnected, it is not applicable to calculate the overall energy saving potential by linear addition of all the energy saving potential for each individual ERMs without conducting the integrated simulation. For instance, the installations of GSHP will lead to higher electricity consumptions, which on the other hand, could be compromised by the installations of solar PV system. Similarly, due to the complexity and time-consuming simulation process, it is very difficult to model all the possible ERMs combinations at the initial design stage. Thus, it is significantly crucial to adopt a rapid assessment approach to reduce the simulation efforts and aid the decision making process in the planning stage of building retrofit.

Energy performance certification (EPC) has been adopted by most European countries as a Passive House design standard. UK government has set a minimum EPC grade E for the residential and commercial properties with approximately $440 \mathrm{kWh} / \mathrm{m}^{2}$ annual primary energy consumption, which will affect $18 \%$ of commercial properties in England and Wales with house ratings of "F" or "G" (Davidson, 23rd March 2018). As for the Norwegian regulations, the minimum requirement is annually $120 \mathrm{kWh} / \mathrm{m}^{2}$ of primary energy consumption for Passive House standard (Skaran, 2013). Although EPC standard is becoming an important energy consumption indicator (Collins \& Curtis, 2018; Droutsa, Kontoyiannidis, Dascalaki, \& Balaras, 2016; Li, Kubicki, Guerriero, \& Rezgui, 2019; Pascuas, Paoletti, \& Lollini, 2017) in the real estate market, only few literature (Balaras, Dascalaki, Droutsa, \& Kontoyiannidis, 2016; Belpoliti, Bizzarri, Boarin, Calzolari, \& Davoli, 2018; Fan \& Xia, 2018; Fregonara et al., 2017; Monzón \& López-Mesa, 2018) investigated the decision-making process with EPC upgrading as one of the retrofit motivations goals. Besides, few attempts have been made to evaluate the relationships between the retrofit combinations and their EPC upgrading capacity. From the 
115 decision-making perspective, it would be beneficial to adopt a rapid, user-friendly and EPC related approach to facilitate the combinations and selections of various ERMs.

117 This paper aims to develop a holistic EPC related building retrofit approach for a residential 118 apartment building in Oslo. Based on the existing building condition and pre-retrofit survey, 11911 different ERMs are exemplified and grouped into 3 levels energy efficient measures (passive, active and renewable measures) according to the potential amount of energy reduction and carbon emission. With the aim to reduce the complicated and time-consuming simulation process for random combinations of various ERMs, 18 combination packages (COMBs) are selected based on the aforementioned principles (Fabric priority, Renewable in supplement, and Avoid complicated installation process). These COMBs are categorized into 4 levels

125 (Moderate Retrofit-I, II, III, and Extensive Retrofit) with respect to the depth of energy saving potentials defined by EU policy paper (Artola, 2016). The EPC related building retrofit approach is then conducted using in two steps: i) The obtained post retrofit annual primary energy consumptions for the 18 combination packages are ranked according to Norwegian EPC standard. ii) By introducing the novel ELD (Energy Limiting Difference) assessment factor, which only considering the difference of primary/renewable energy consumption in the extreme winter and summer months, the post retrofit EPC standard for each combination package are linked with the difference of maximum and minimum primary energy consumption and available renewable energy. The relationship between ELD assessment factors and relevant

134 EPC grades for the 18 combination packages is plotted and verified against the obtained EPC 135 results from step i). It can be found that instead of performing the annual primary energy consumption with any random retrofit combinations, the novel EPC related building retrofit approach establish a rapid and direct link between EPC grades upgrading and retrofit combination packages with the help of ELD assessment factors, which enables the holistic retrofit assessment for any possible ERMs. Hence, by adopting the proposed EPC related 
140 retrofit approach, the time efforts for the energy simulation is only about $22 \%$ of that for 141 conventional approach, which significantly facilitates the rapid retrofit design and decision-

142 making process. This holistic retrofit approach provides useful guidance for the similar 143 apartment block retrofit incorporating renewable energy measures in the cold climate region, 144 and could be replicable for other building retrofit projects in Europe. The structure of this paper 145 is organized as following: Section 2 discusses about the methodology applied in this research 146 at three levels, which are individual ERM level, combination package level ang EPC 147 assessment level. Section 3 describes the existing building conditions, simulation hypothesis, 148 baseline building model, the selected ERMs and their combination packages. Section 4 149 discusses about the primary energy and carbon emission reduction for each selected COMBs. 150 The rapid EPC related retrofit approach using novel ELD assessment factor is also analysed and compared with the conventional approach. The key research findings and future works are summarized in section 5 .

\section{Holistic EPC Related Retrofit Approach}

In this research, the following holistic EPC related retrofit approach (shown in Fig. 1) has been applied: Firstly, a pre-retrofit site inspection is carried out with the aim to identify the existing building post-construction conditions, which aims to collect the essential information for building energy modelling stage. Besides, building occupant survey are conducted to analyse the energy usage patterns and occupancy's behaviours. Secondly, the demo site building model is established in the simulation software (i.e., IES VE) with the local weather data acquired 160 from Energy Plus. Thirdly, the existing annual energy consumption bills will be used to validate and modify the established model. The adjusted model could provide a high degree of accuracy and facilitate the further predication and calculation of energy saving potentials for the various combination packages. Fourthly, at individual energy retrofit measure level, taking into considerations of existing building conditions, local planning permission, a list of energy 
retrofit measures ERMs are proposed and grouped into three different categories (passive, active and renewable energy measures). At the ERM combination level, 18 different combination packages are defined based on the building retrofit levels defined by EU policy paper (Artola, 2016). Finally, all the combination packages will be assessed and ranked using 169 the innovative EPC related retrofit approach based on ELD assessment factor, which greatly reduces the simulation efforts and facilitates the retrofit decision-making process.

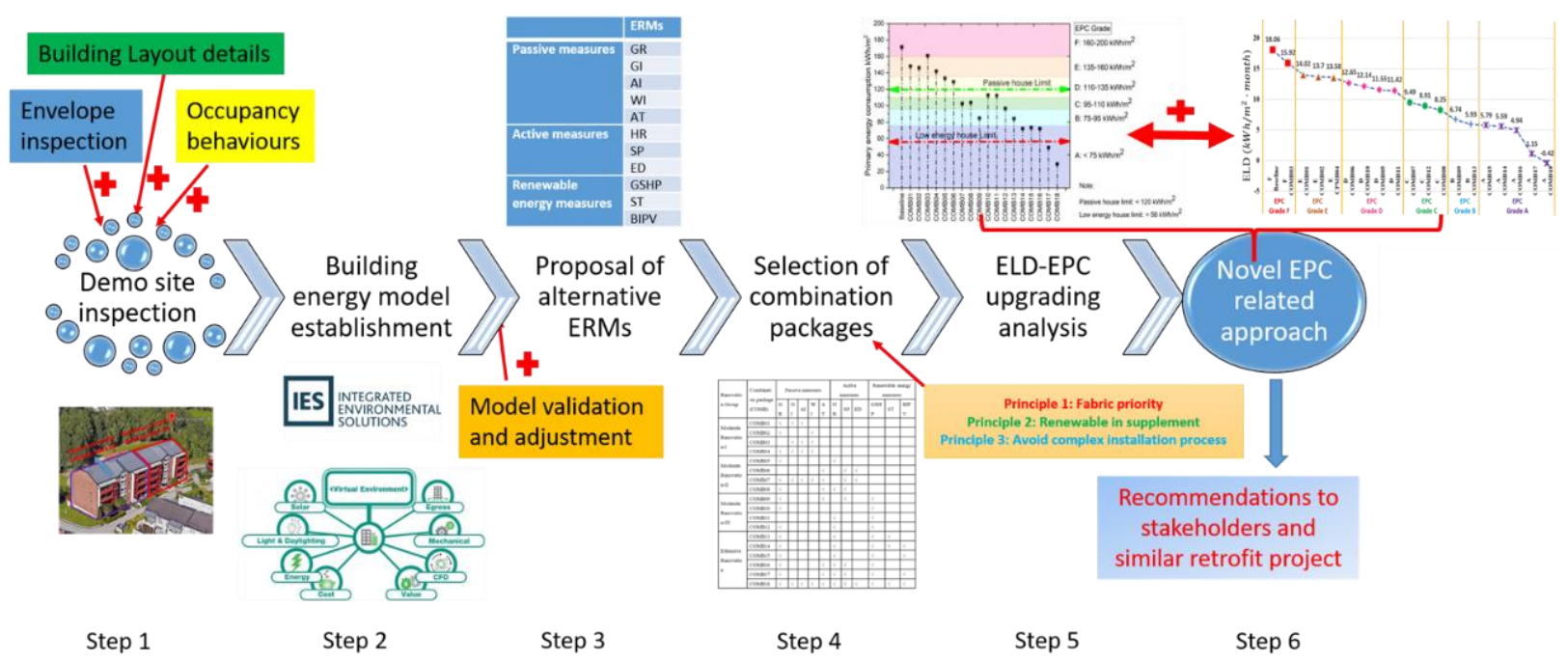

Fig. 1 Research Methodology of the holistic EPC related retrofit approach

173

\subsection{Individual ERMs level and classification principle}

The selected energy retrofit measures (ERMs) are grouped into passive, active and renewable measures, based on the following selection criteria:

1) Passive measures: ERMs related to partially changing the building components, including but not limited to upgrading the existing building fabric and service systems with more energy efficient systems, etc.;

2) Active measures: ERMs including installation of heating set point schedule, smart meter, efficient lighting system, improving the air tightness of the building, etc.;

3) Renewable energy measures: ERMs making use of renewable energy resources, such as ground source heat pump (GSHP), solar PV, solar thermal collector that can be incorporated into the existing building. 


\subsection{EPC standard selection --- based on ELD assessment factor}

185 The Norwegian buildings can be classified in the range of grade F to A, according to its EPC 186 standard ("Byggteknisk forskrift (TEK17)," 2017). In order to satisfy the current passive building design code in Norway (Skaran, 2013), EPC level should be at least grade C or above with annual energy consumption less than $110 \mathrm{kWh} / \mathrm{m}^{2}$. Based on the simulation obtained annual energy consumptions, the proposed 18 combination packages are ranked according to their EPC grades, which provide clear indications for their annual energy saving potentials. In order to avoid the complicated simulation process with all the possible combination packages, we developed a novel EPC related approach using an assessment factor, i.e, Energy Limiting Difference (ELD), which is defined as the maximum and minimum monthly energy consumption difference over a year for each retrofit combination package. This assessment approach is based on the assumption that the maximum energy reduction potential is relevant to the maximum primary and renewable energy difference over a year for any defined retrofit combination.

198 Reflecting the energy saving potentials, ELD can be calculated as the differences of two factors, including: 1) the primary energy consumption of the grid imported thermal energy and the grid imported electricity; 2) the renewable energy contributions. The calculation method of ELD is shown in Equations (1)-(7):

$$
\begin{aligned}
& E L D=\Delta(P E)_{\text {max }, m}-\Delta(R E)_{\text {max }, m} \\
& \Delta(P E)_{\text {max }, m}=P E_{\text {max }, m}-P E_{\text {min }, m} \\
& P E_{\text {max }, m}=\left(P E_{e, \max }\right)_{m}+\left(P E_{t, \text { max }}\right)_{m} \\
& P E_{\text {min }, m}=\left(P E_{e, \min }\right)_{m}+\left(P E_{t, \text { min }}\right)_{m} \\
& \Delta(R E)_{\text {max }, m}=R E_{\text {max }, m}-R E_{\text {min }, m} \\
& R E_{\text {max }, m}=\left(R E_{e, \max }\right)_{m}+\left(R E_{t, \text { max }}\right)_{m} \\
& R E_{\text {min }, m}=\left(R E_{e, \min }\right)_{m}+\left(R E_{t, \text { min }}\right)_{m}
\end{aligned}
$$


209 In these equations, ELD is the maximum monthly energy limiting difference. The assessment 210 factor, i.e., ELD with a smaller value represents better post-retrofit energy performance for the 211 selected COMBs. $\Delta(P E)_{\max , m}$ represents the maximum monthly primary energy difference,

212 which consists of two parts i) the difference of the maximum $\left(P E_{e, \max }\right)$ and minimum $\left(P E_{e, \min }\right)$ 213 monthly primary electricity energy consumption; ii) the difference of the maximum $\left(P E_{t, \max }\right)$

214 and minimum $\left(P E_{t, \min }\right)$ monthly thermal energy consumption. $\Delta(R E)_{\max , m}$ represents the maximum monthly renewable energy difference, which is the sum of two parts :i) the difference between the maximum $\left(R E_{e, \max }\right)$ and minimum $\left(R E_{e, \min }\right)$ monthly renewable electricity

217 energy, and ii) the difference of the maximum $\left(R E_{t, \max }\right)$ and minimum $\left(R E_{t, \min }\right)$ monthly 218 renewable thermal energy.

219 Taking COMB 14 as an example, the process of identifying the ELD assessment factor is 220 shown in Fig. 2. Being the coldest month throughout the year in Oslo, January poses the 221 maximum primary energy consumption with the minimum amount of renewable energy 222 available. In contrast, as the hottest month with sufficient solar energy during a year, June 223 yields the minimum primary energy consumption with the maximum amount of available renewable energy. Therefore, the maximum thermal energy difference is occurred between point $1\left(P E_{t, \max }\right)$ and $2\left(P E_{t, \min }\right)$, with the maximum electricity difference between point 3 $226\left(P E_{e, \max }\right)$ and $4\left(P E_{e, \max }\right)$. In terms of renewable energy, the maximum renewable thermal 227 energy difference occurs between points $5\left(R E_{t, \max }\right)$ and $6\left(R E_{t, \min }\right)$, with the maximum 228 electricity difference between points $7\left(R E_{e, \max }\right)$ and $8\left(R E_{e, \max }\right)$. The detailed discussion of this approach will be included in section 4.2. 


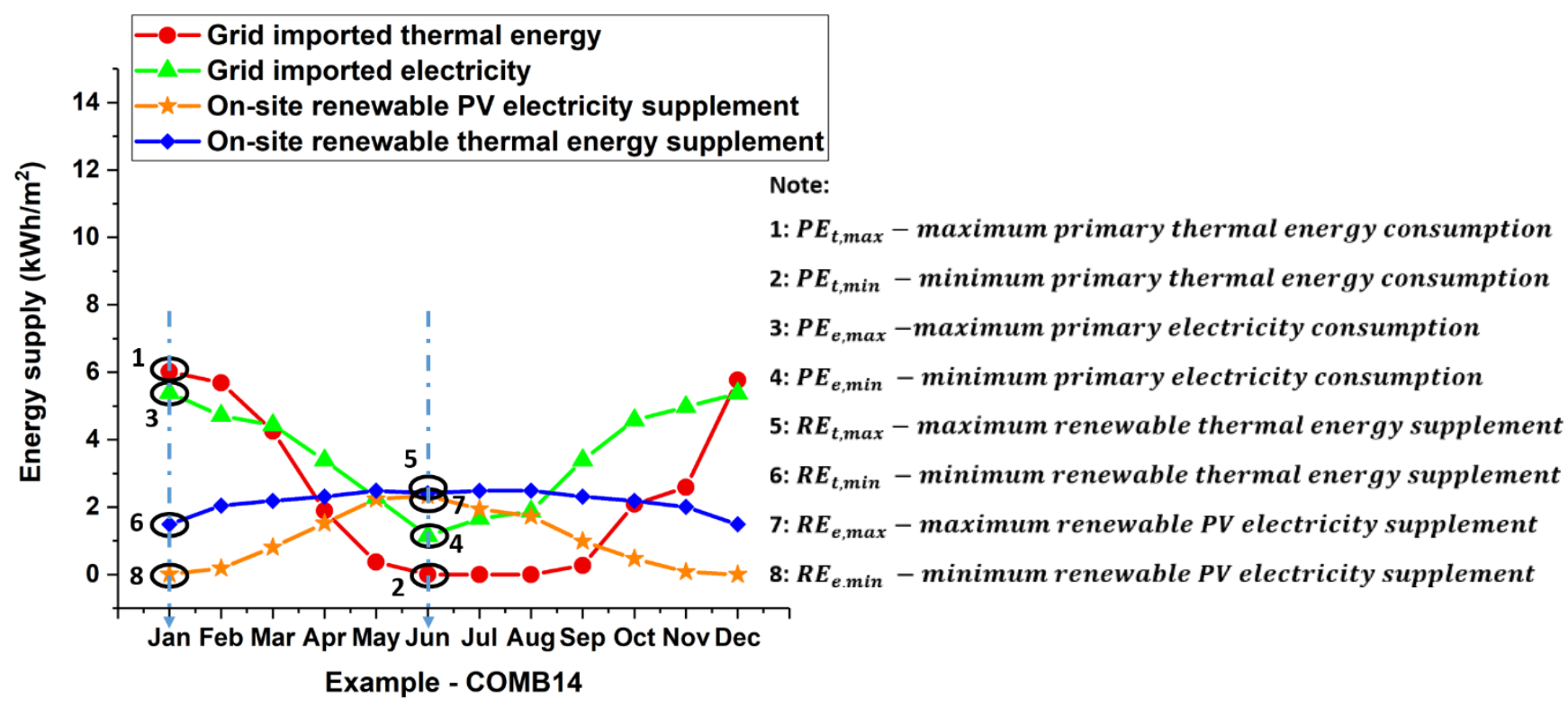

Fig. 2 Representative example of ELD assessment factor calculation

\section{Model establishment and selection of combination packages}

234

235

\subsection{Demo site building description}

This research will develop a holistic retrofit method for rapid energy upgrading of residential building blocks in the Oslo district, which is supported by EU Horizon 2020 funded project RezBuild ("REZBUILD Project," 2019). The selected demo site building in this research is located at the Bertramjordet condominium in Rosenholmveien, which is approximately $14 \mathrm{~km}$ from the centre of Oslo. The apartment block No.64 in the Bertramjordet complex was chosen as the demo site building, which is shared with an internal partition wall with Block 63 to constitute a whole apartment block. The southeast and aerial views of the demo site building are shown in Fig. 3 and Fig. 4 respectively. Built in 1987, it was a four-storey apartment block with the unheated basement, top level attic and 12 flats (half of the whole apartment building). The total building floor area is approximately $1839.4 \mathrm{~m}^{2}$, including heated area of $934.2 \mathrm{~m}^{2}$ and unheated area of $905.2 \mathrm{~m}^{2}$. Each flat in this apartment has an average of $77.85 \mathrm{~m}^{2}$ dwelling area. 


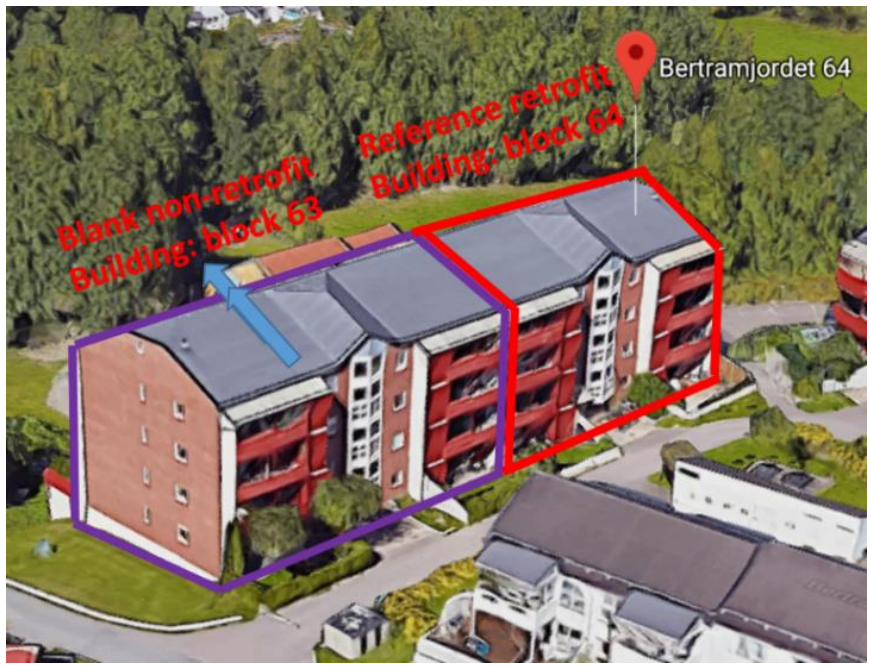

248

Fig. 3 Southeast view of the demo site building

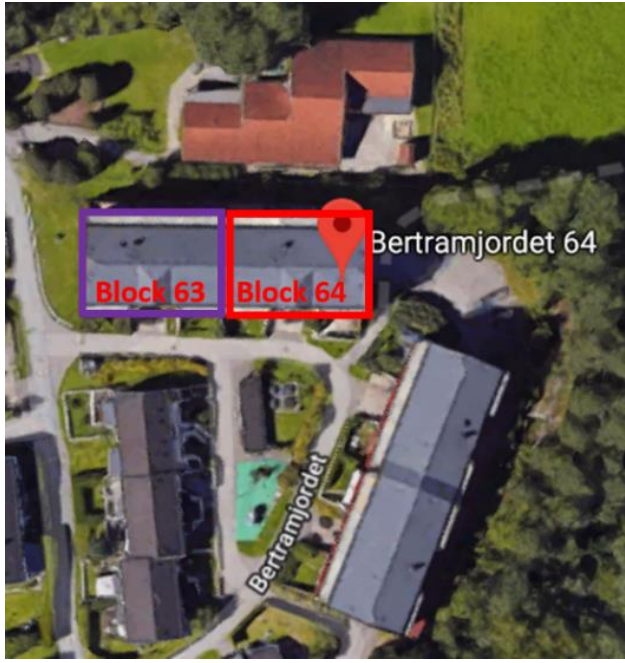

Fig. 4 Aerial view of demo site building

\subsection{Building energy model construction and validation}

Several site inspections, surveys and meetings with the Bertramjordet cooperatives(Biswas et al., 2018) were conducted by the project partner OBOS ("OBOS Bastart," 2019) from October

2016 to March 2017. Detailed fabric construction layers, thermal conductivities, and the overall

U-value of the building envelopes are summarized in Table 2 (cooperatives, May 2017), which and low-energy buildings - Residential buildings," 2013) for Passive houses.

Table 2 Building fabric details of the demo site building (cooperatives, May 2017)

\begin{tabular}{|l|l|l|l|}
\hline Construction & Thickness & U-value $\left(W / m^{2} \cdot K\right)$ & Maximum U-values \\
& & & according to NS3700 for \\
Passive houses $\left(W / m^{2} \cdot K\right)$
\end{tabular}




\begin{tabular}{|l|l|l|l|}
\hline External gamble wall & $280 \mathrm{~mm}$ & 0.32 & 0.18 \\
\hline External balcony wall & $160 \mathrm{~mm}$ & 0.23 & 0.18 \\
\hline Glazing & & 3.13 & 0.8 \\
\hline Internal partition & $205 \mathrm{~mm}$ & 2.19 & N/A \\
\hline Internal ceiling & $210 \mathrm{~mm}$ & 0.35 & N/A \\
\hline Flat entrance door & $30 \mathrm{~mm}$ & 2.80 & 0.8 \\
\hline Roof & $156 \mathrm{~mm}$ & 0.89 & \multirow{2}{*}{0.13} \\
\hline Attic insulation & $420 \mathrm{~mm}$ & 0.18 & \\
\hline
\end{tabular}

258 Human behaviours including comfortable temperature ranges, occupancy profiles and the 259 household equipment usage patterns are proven to affect the building energy performance 260 significantly ("Standard 55-2013 -- Thermal Environmental Conditions for Human 261 Occupancy," 2013). A post occupancy survey revealed that the current building occupancy is a mixture between retired pensioners and families with children. The occupancy profile was defined with the heating system on during the winter season (from $1^{\text {st }}$ September to $30^{\text {th }}$ May). The current district heating system in the baseline model was considered as $24-7$ constant room temperature around $21^{\circ} \mathrm{C}$. In the model, two kinds of air exchange conditions including air infiltration and mechanical ventilation were considered. The mechanical ventilation rate of the demo site building was assumed as $8.5 \mathrm{~m}^{3} \cdot \mathrm{h}^{-1} / \mathrm{m}^{2}$ at 50 Pa pressure difference (Engineers, March 2015). Referring to other retrofitting projects in similar climatic condition in Finland (Niemelä, Kosonen, \& Jokisalo, 2017), Sweden (Dodoo, Gustavsson, \& Tettey, 2017) and Norway (Nord, Løve Nielsen, Kauko, \& Tereshchenko, 2018) and the ASHARE guide (Tor 271 Helge Dokka, 2013), the corresponding average ventilation rate is set as $0.85 \mathrm{ACH}$, including

$27230 \mathrm{~L} / \mathrm{s}$ and 15L/s in kitchen and bathroom, respectively. The air infiltration rate is considered as 0.6 $\mathrm{ACH}$. The space heating and domestic hot water (DHW) of this apartment block are 
supplied by a district heating system, which is powered waste incineration. The detailed model 275 input data are summarized in Table 3.

Table 3 IES VE model input data or ASHRAE and CIBSE Guide

\begin{tabular}{|c|c|c|}
\hline $\begin{array}{l}\text { District } \\
\text { heating } \\
\text { (cooperatives, }\end{array}$ & $\begin{array}{l}\text { Winter: on (temperature } \\
\text { maintained constant at } \\
21^{\circ} \mathrm{C} \text { ) }\end{array}$ & 01 Sep to 31 May \\
\hline May 2017) & Summer: off & $1^{\text {st }}$ June to 31 Aug \\
\hline District & Seasonal efficiency & $80 \%$ \\
\hline heating & Heat delivery efficiency & $90 \%$ \\
\hline $\begin{array}{l}\text { (Francisco } \\
\text { Pinto \& }\end{array}$ & $\begin{array}{l}\text { Average water inlet } \\
\text { temperature }\end{array}$ & $10^{\circ} \mathrm{C}$ \\
\hline $\begin{array}{l}\text { Carrilho da } \\
\text { Graça, 2018; } \\
\text { Nord et al., } \\
2018 \text { ) }\end{array}$ & $\begin{array}{l}\text { Hot water supply } \\
\text { temperature }\end{array}$ & $60^{\circ} \mathrm{C}$ \\
\hline $\begin{array}{l}\text { Ventilation } \\
\text { (Niemelä et }\end{array}$ & Mechanical ventilation & $\begin{array}{l}0.85 \mathrm{ACH}(30 \mathrm{~L} / \mathrm{s} \text { in kitchen and } 15 \mathrm{~L} / \mathrm{s} \text { in } \\
\text { bathroom })\end{array}$ \\
\hline $\begin{array}{l}\text { al., 2017) } \\
\text { (Baumhof et } \\
\text { al.) (Ascione, } \\
\text { Bianco, De } \\
\text { Stasio, } \\
\text { Mauro, \& } \\
\text { Vanoli) }\end{array}$ & Infiltration & $0.6 \mathrm{ACH}$ \\
\hline
\end{tabular}




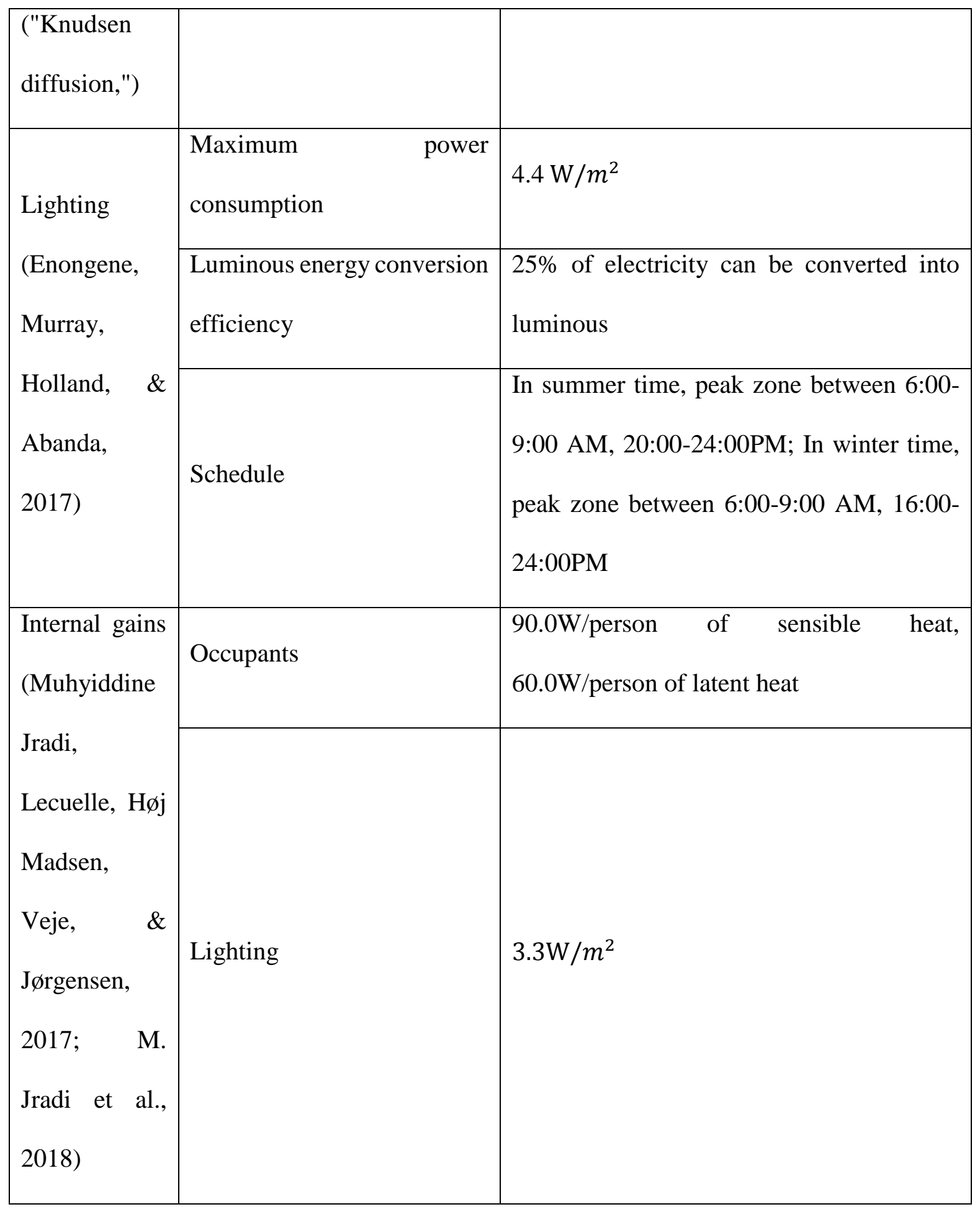




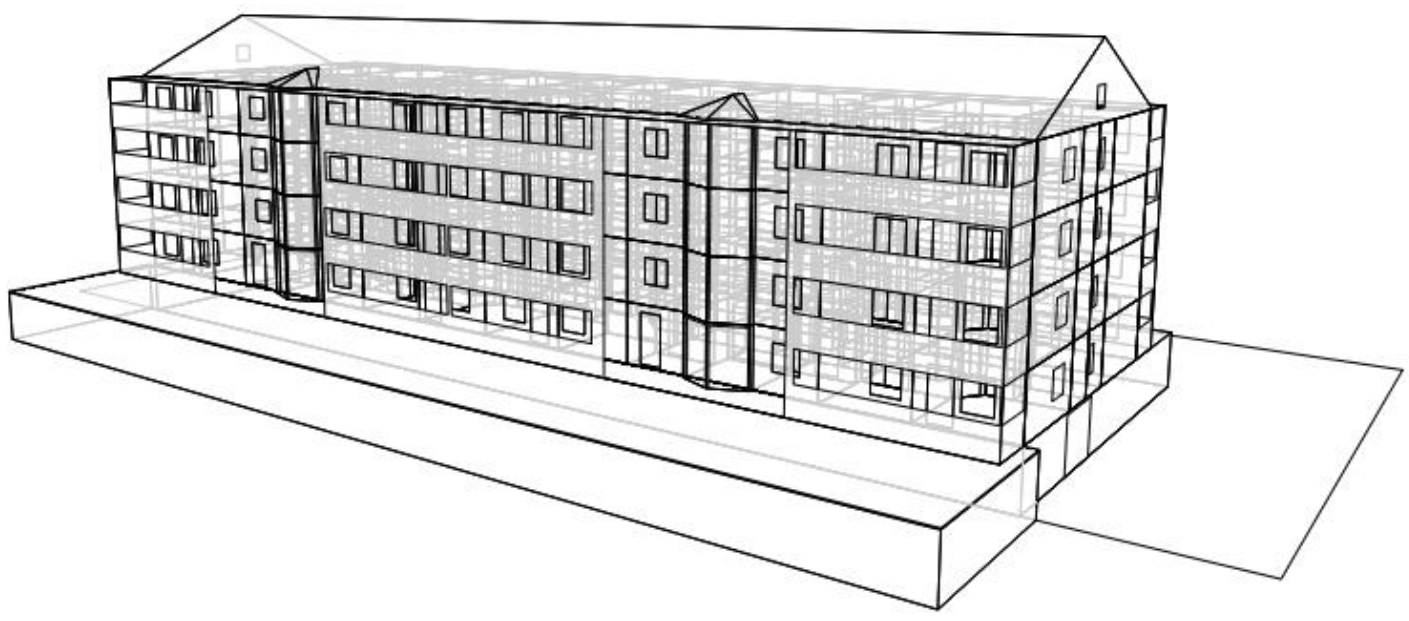

Fig. 5 Baseline geometry model of the residential block in IES VE

280 After the building fabric conditions and the model input parameters were defined, the demo 281 site building model (as shown in Fig.5) was established in IES VE. In the demo site building, 282 district heating is the main supply for both space heating and hot water. Three-year district 283 heating consumptions from 2014 to 2016 (shown in Table 4) are used to compare and verify 284 the established baseline model, with the aim to accurately simulate the energy performance for 285 the building.

Table 4 Monitored and calculated district heating energy

\begin{tabular}{|c|c|c|c|}
\hline & 2014 & 2015 & 2016 \\
\hline Annually monitored overall district heating energy $(\mathrm{kWh})$ & 118830 & 119682 & 125819 \\
\hline Annually monitored specific district heating energy $\left(\mathrm{kWh} / \mathrm{m}^{2}\right)$ & 127.2 & 128.1 & 134.7 \\
\hline Calculated district heating energy in building energy model $\left(\mathrm{kWh} / \mathrm{m}^{2}\right)$ & \multicolumn{2}{|c|}{129} \\
\hline
\end{tabular}

\section{$288 \quad 3.3$ Baseline model energy simulation results}

289 In the building baseline model, the annual primary energy consumption of the building was 290 calculated as $172 \mathrm{kWh} / \mathrm{m}^{2}$, which includes $103 \mathrm{kWh} / \mathrm{m}^{2}$ of space heating, $43 \mathrm{kWh} / \mathrm{m}^{2}$ of 291 electricity consumption, and $26 \mathrm{kWh} / \mathrm{m}^{2}$ of DHW. According to Norway EPC standard, this 
292 demo site building will be ranked as F grade, which is far below the current required passive 293 house standard (A, B or C grade) in Norway.

294 In addition to the annual energy consumption and heat loss, it is useful to analyse the monthly 295 energy consumption of the building to identify the variation of electricity and heating demands. 296 Fig. 6 shows the monthly space heating, domestic hot water and electricity consumption of the 297 building by conducting the simulation in the IES VE software. It is shown that January is the 298 month with the highest energy consumption of about 21.85 MWh, which is the sum of primary 299 electricity consumption from grid and primary thermal energy consumption from district 300 heating. Over the whole year, space heating consumes the most energy compared with 301 electricity and domestic hot water (DHW).

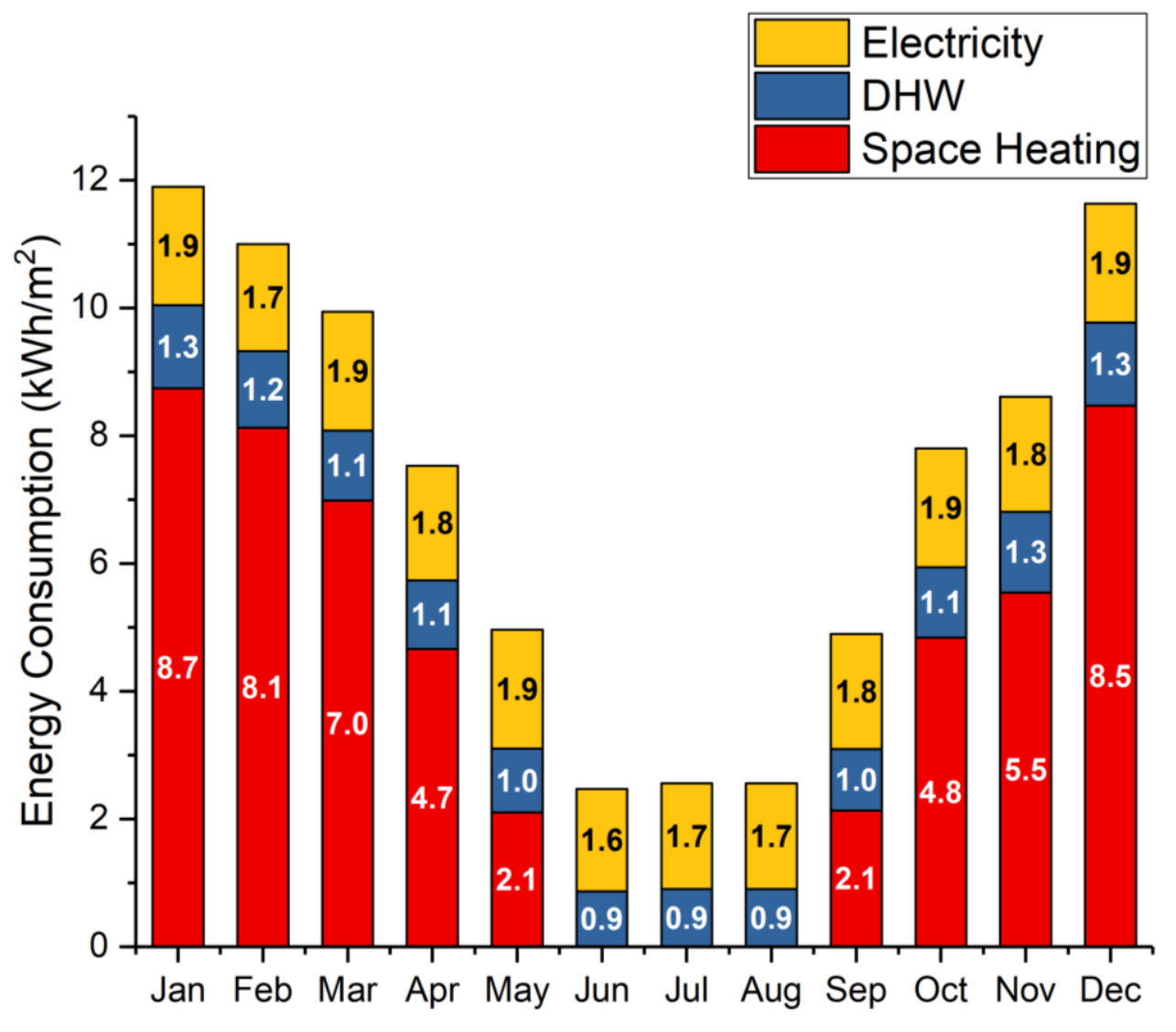

Fig. 6 Monthly final energy consumption profile 


\subsection{Index of proposed alternative energy retrofit measures (ERMs)}

305

306

The selected three level ERMs with the detailed technical specifications are summarized in Table 5. All the technical specifications were obtained from the RezBuild project partners, available product manufacturers or technology developers. The technical parameters used in Table 3 are explained below: $\mathrm{U}_{\mathrm{w}}$ is the external wall thermal transmittance; $\mathrm{U}_{\mathrm{a}}$ is the roof slab thermal transmittance; $\mathrm{U}_{\mathrm{g}}$ is the garage slab thermal transmittance; $\mathrm{U}_{\mathrm{gl}}$ is the glazing thermal transmittance; $\mathrm{d}$ is the thickness of the insulation materials; $\eta$ is the efficiency of the heat recovery system; COP is the efficiency of the solar thermal collector and BIPV panel, EER is the system energy efficiency ratio.

Table 5 Technical specification for selected ERMs

\begin{tabular}{|c|c|c|c|}
\hline & Energy measures & Nomenclature & Technical specification \\
\hline \multirow{5}{*}{$\begin{array}{l}\text { Passive } \\
\text { measures }\end{array}$} & Triple glazing & GR & $\mathrm{U}_{\mathrm{gl}}=0.62 \mathrm{~W} / \mathrm{m}^{2} \mathrm{~K}$ \\
\hline & $\begin{array}{l}\text { Garage celling } \\
\text { insulation }\end{array}$ & GI & $\begin{array}{l}\mathrm{U}_{\mathrm{g}}=0.1 \mathrm{~W} / \mathrm{m}^{2} \mathrm{~K}, \quad \text { Vacuum insulation } \\
\text { panel }\end{array}$ \\
\hline & Attic floor insulation & AI & $\mathrm{U}_{\mathrm{a}}=0.1 \mathrm{~W} / \mathrm{m}^{2} \mathrm{~K}$, Vacuum insulation panel \\
\hline & $\begin{array}{l}\text { Wall insulation } \\
\text { upgrading }\end{array}$ & WI & $\begin{array}{l}\mathrm{U}_{\mathrm{w}}=0.1 \mathrm{~W} / \mathrm{m}^{2} \mathrm{~K}, \text { Vacuum insulation } \\
\text { panel }\end{array}$ \\
\hline & $\begin{array}{l}\text { Air tightness } \\
\text { improvement }\end{array}$ & AT & EPDM foil system \\
\hline \multirow{3}{*}{$\begin{array}{l}\text { Active } \\
\text { measures }\end{array}$} & Heat recovery system & HR & Effectiveness: $86 \%$ \\
\hline & Temperature sensor & SP & $\begin{array}{l}\text { Temperature set decrease to } 21^{\circ} \mathrm{C} \text { in } \\
\text { winter }\end{array}$ \\
\hline & $\begin{array}{l}\text { Efficient lighting } \\
\text { device }\end{array}$ & ED & $\begin{array}{l}\text { LED lighting with } 40 \% \text { electricity } \\
\text { consumption reduction }\end{array}$ \\
\hline
\end{tabular}




\begin{tabular}{|c|c|c|c|}
\hline $\begin{array}{l}\text { Renewable } \\
\text { energy }\end{array}$ & $\begin{array}{l}\text { Ground source heat } \\
\text { pump }\end{array}$ & GSHP & Heat capacity of $18.7 \mathrm{~kW}, \mathrm{COP}: 3.4$ \\
\hline \multirow[t]{2}{*}{ measures } & $\begin{array}{l}\text { Flat solar thermal } \\
\text { collector }\end{array}$ & ST & $\begin{array}{l}\text { Collector area }=172.8 \mathrm{~m}^{2}, \text { Tilt angle } 25^{\circ} \\
\text { Solar heat generation efficiency: } 47 \%\end{array}$ \\
\hline & $\begin{array}{l}\text { Building Integrated } \\
\text { Photovoltaics }\end{array}$ & BIPV & $\begin{array}{l}\mathrm{A}=192 \mathrm{~m}^{2} \text {, Tilt angle } 25^{\circ}, 28.9 \mathrm{~kW}_{p} \\
\mathrm{PV} \quad \text { electricity generation } \\
\text { efficiency: } 18.8 \%\end{array}$ \\
\hline
\end{tabular}

\subsection{Retrofit combination packages}

According to EU policy paper(Artola, 2016), building retrofit levels could be classified into four categories: minor retrofits, moderate retrofits, extensive retrofits and almost zero-energy building retrofits, which corresponds to energy consumption reduction in the range of $0-30 \%$, $30-60 \%, 60-90 \%$ and beyond, respectively. Based on the 3 pre-combination principles with "fabric priority", "renewable in supplement", and "avoid complicated installation process". COMB01-COMB04 are combinations with only passive measures, which is referring to the fabric improvement. In the site building, the total wall area is $550.55 \mathrm{~m}^{2}$ and the glazing area is $102.05 \mathrm{~m}^{2}$. Therefore, the ratio of window/wall is approximately $18.5 \%$, which results in a large energy saving potential of the glazing retrofit. As shown in Table 6, a total of 18 ERMs combination packages have been categorized into 4 levels: "Moderate Retrofit-I, II, III" and "Extensive Retrofit" according to the 3 pre-combination classification principles. Moderate Retrofit-I" focus on integrating of the passive ERMs into the baseline. "Moderate Retrofit-II" is the combination between the selected active ERMs and passive ERMs. "Moderate Retrofit329 III" includes passive ERMs, active ERMs with only 1 renewable ERM. Finally, the combinations of passive ERMs, active ERMs and at least 2 renewable ERMs are considered in "Extensive Retrofit". 
Table 6 Retrofit combination packages

\begin{tabular}{|c|c|c|c|c|c|c|c|c|c|c|c|c|}
\hline \multirow{2}{*}{$\begin{array}{l}\text { Retrofit } \\
\text { Group }\end{array}$} & \multirow{2}{*}{$\begin{array}{l}\text { Combination } \\
\text { package } \\
(\mathrm{COMB})\end{array}$} & \multicolumn{5}{|c|}{ Passive measures } & \multicolumn{3}{|c|}{$\begin{array}{l}\text { Active } \\
\text { measures }\end{array}$} & \multicolumn{3}{|c|}{$\begin{array}{c}\text { Renewable energy } \\
\text { measures }\end{array}$} \\
\hline & & GR & GI & $\mathrm{AI}$ & WI & AT & HR & SP & ED & GSHP & ST & BIPV \\
\hline \multirow{4}{*}{$\begin{array}{l}\text { Moderate } \\
\text { Retrofit-I }\end{array}$} & COMB01 & $\sqrt{ }$ & $\sqrt{ }$ & $\sqrt{ }$ & & & & & & & & \\
\hline & COMB02 & $\sqrt{ }$ & & & $\sqrt{ }$ & & & & & & & \\
\hline & COMB03 & & $\sqrt{ }$ & $\sqrt{ }$ & $\sqrt{ }$ & & & & & & & \\
\hline & COMB04 & $\sqrt{ }$ & $\sqrt{ }$ & $\sqrt{ }$ & $\sqrt{ }$ & & & & & & & \\
\hline \multirow{4}{*}{$\begin{array}{l}\text { Moderate } \\
\text { Retrofit-II }\end{array}$} & COMB05 & $\sqrt{ }$ & & & & & $\sqrt{ }$ & & & & & \\
\hline & COMB06 & & & & & $\sqrt{ }$ & & $\sqrt{ }$ & $\sqrt{ }$ & & & \\
\hline & COMB07 & $\sqrt{ }$ & $\sqrt{ }$ & $\sqrt{ }$ & $\sqrt{ }$ & $\sqrt{ }$ & & $\sqrt{ }$ & $\sqrt{ }$ & & & \\
\hline & COMB08 & $\sqrt{ }$ & & & & $\sqrt{ }$ & $\sqrt{ }$ & $\sqrt{ }$ & & & & \\
\hline \multirow{4}{*}{$\begin{array}{l}\text { Moderate } \\
\text { Retrofit-III }\end{array}$} & COMB09 & $\sqrt{ }$ & & & & $\sqrt{ }$ & & $\sqrt{ }$ & & $\sqrt{ }$ & & \\
\hline & COMB10 & $\sqrt{ }$ & & & & & & & & $\sqrt{ }$ & & \\
\hline & COMB11 & & & & & & $\sqrt{ }$ & & & $\sqrt{ }$ & & \\
\hline & COMB12 & $\sqrt{ }$ & & & & & $\sqrt{ }$ & & & $\sqrt{ }$ & & \\
\hline \multirow{6}{*}{$\begin{array}{l}\text { Extensive } \\
\text { Retrofit }\end{array}$} & COMB13 & $\sqrt{ }$ & & & & & $\sqrt{ }$ & & & $\sqrt{ }$ & $\sqrt{ }$ & \\
\hline & COMB14 & $\sqrt{ }$ & & & & & $\sqrt{ }$ & & & $\sqrt{ }$ & $\sqrt{ }$ & $\sqrt{ }$ \\
\hline & COMB15 & $\sqrt{ }$ & & & & & $\sqrt{ }$ & & & $\sqrt{ }$ & & $\sqrt{ }$ \\
\hline & COMB16 & $\sqrt{ }$ & & & & $\sqrt{ }$ & $\sqrt{ }$ & $\sqrt{ }$ & & $\sqrt{ }$ & & \\
\hline & COMB17 & $\sqrt{ }$ & & & & $\sqrt{ }$ & $\sqrt{ }$ & $\sqrt{ }$ & & $\sqrt{ }$ & & $\sqrt{ }$ \\
\hline & COMB18 & $\sqrt{ }$ & $\sqrt{ }$ & $\sqrt{ }$ & $\sqrt{ }$ & $\sqrt{ }$ & $\sqrt{ }$ & $\sqrt{ }$ & $\sqrt{ }$ & $\sqrt{ }$ & $\sqrt{ }$ & $\sqrt{ }$ \\
\hline
\end{tabular}


333

334

335

336

337

338

339

340

341

342

343

344

345

346

347

\section{Retrofit simulation results and discussion}

\subsection{Primary energy consumption, carbon emission and EPC assessment of ERM}

combinations

After defining the combination packages in section 3.5, the established baseline model was updated by incorporating the 18 COMBs respectively. For each individual COMB, the monthly energy consumption and the primary energy consumption were simulated. Primary energy consumption is calculated as the sum of thermal energy consumption supplied by district heating and electricity consumption supplied by electricity grid. Besides, the $\mathrm{CO}_{2}$ emission is calculated by the sum of each energy components multiplied by their different weighting factors. The obtained primary energy consumption and $\mathrm{CO}_{2}$ emission are presented in Table 7 . In general, the maximum possible energy reduction occurs in COMB18 due to the fact that it incorporates all ERMs. Compared with the baseline results, the final energy consumption and the $\mathrm{CO}_{2}$ emissions of $\mathrm{COMB} 18$ is reduced by $83 \%$ to $29 \mathrm{kWh} / \mathrm{m}^{2} \cdot$ year and $88 \%$ to $4.2 \mathrm{kgCO}_{2} / \mathrm{m}^{2} \cdot$ year, respectively.

The assessment of EPC grade of all combination packages is summarized in Fig. 7. In "Moderate Retrofit I", the EPC grade upgrades from F into E, with a maximum final energy reduction of $17 \%$ to $142 \mathrm{kWh} / \mathrm{m}^{2} \cdot$ year in COMB04. Therefore, the COMBs in "Moderate Retrofit I" will not be able to achieve the expected energy saving targets for Norwegian Passive house standard. It can be noted that the installation of additional insulation layers on the existing building fabric, and the upgrading of double-glazing with triple glazing is the most promising passive ERM, contributing significantly to the primary energy reduction. Most of the combination packages within "Moderate Retrofit II and III" satisfy the EPC grade B, C and $\mathrm{D}$, with a primary energy reduction of $44 \%$ to $96.6 \mathrm{kWh} / \mathrm{m}^{2} \cdot$ year in COMB12. It can be concluded that among "Moderate Retrofit II", the most promising combination packages is COMB08 which integrates only 4 ERMs $(\mathrm{GR}+\mathrm{HR}+\mathrm{AT}+\mathrm{SP})$ but achieving a $39 \%$ of final 
energy reduction. Consisting of 4 ERMs (GR+AT+SP+GSHP) in "Moderate Retrofit III", COMB09 can reduce $77.5 \%$ of heating energy with $30 \%$ increase of imported grid electricity. COMB12 consists of only 3 ERMs (GR+HR+GSHP), which reduces $71.0 \%$ of heating energy with $40 \%$ increase of imported grid electricity. Hence, it is obvious that GSHP system can drastically improve the energy efficient of the building. The "Extensive Retrofit" combination packages match well with EPC grade A, with a maximum final energy reduction of $83 \%$ to $29 \mathrm{kWh} / \mathrm{m}^{2} \cdot$ year in COMB18. It should be noted that COMB14 and COMB15 are integrated with ST and BIPV, which will be affected by the intermittent feature of solar radiations. Whilst COMB16 is integrated with AT and SP, which is more stable. Therefore, both AT and SP should be considered before installing renewable ERMs. Further observation of Fig. 7 reveals that COMB09 yields the best energy performance among "Moderate RetrofitIII", which is even comparable with some of combination packages in "Extensive Retrofit" (e.g. COMB13). Meanwhile, two threshold lines presented in the Fig. 7, which represented for the Passive House energy limit and low-energy house limit, with maximum annually 120 $\mathrm{kWh} / \mathrm{m}^{2}$ and $56 \mathrm{kWh} / \mathrm{m}^{2}$ (Tor Helge Dokka, 2013) respectively. Besides, only COMB17 and COMB18 have the ability to reach the low-energy house limit (Tor Helge Dokka, 2013) with at least $67 \%$ of the total energy reduction in this demo site building, which proves that the passive, active and renewable energy measures have to be integrated in one packages to realise the low-energy house standard.

377 From the perspective of carbon reduction, COMB 09, 13-18 could satisfy with the Norwegian passive house standard ("Byggteknisk forskrift (TEK17)," 2017; Thullner, 2010), with the maximum $\mathrm{CO}_{2}$ emission less than $15 \mathrm{kgCO}_{2} / \mathrm{m}^{2} \cdot$ year. Considering the number of ERMs incorporated, COMB09, COMB12, COMB13 and COMB15, which include a maximum of 4 ERMs should be the most energy efficient packages compared with other COMBs. COMB09 includes totally 4 ERMs, especially containing the improvement of air tightness and 
temperature set point control, while the other combinations in "Moderate Retrofit-III" is less than 4 retrofit measures. Besides, improvement of air tightness and temperature set point control have a higher energy saving potential than most of the passive and active retrofit measures, with $14.7 \%$ and $7.3 \%$ respectively. Therefore, although all the combinations in

387 "Moderate Retrofit-III" includes ground source heat pump (GSHP), only COMB09 reach a 388 lower primary energy consumption with $84.9 \mathrm{kWh} / \mathrm{m}^{2}$ year. Amongst these combination packages, the commonly shared individual ERMs are GR, HR, GSHP and BIPV. Therefore, it could be concluded that these four individual ERMs play more significant roles for primary energy saving than other ERMs, which should be highly recommended.

Table 7 Simulation predicted performance of various COMBs

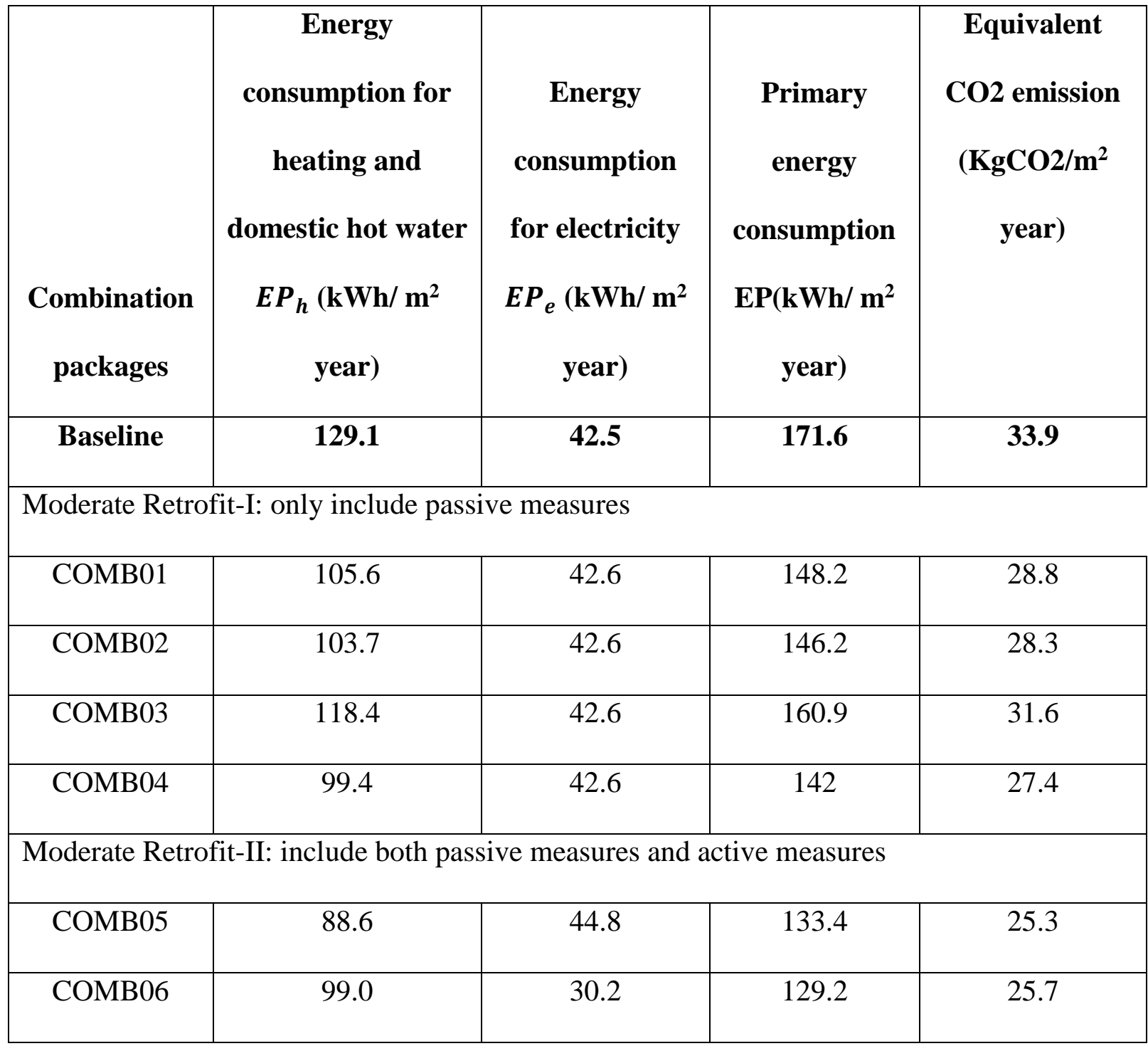




\begin{tabular}{|c|c|c|c|c|} 
COMB07 & 72.5 & 30.2 & 102.6 & 19.9 \\
\hline COMB08 & 59.1 & 44.8 & 103.9 & 18.8 \\
\hline Moderate Retrofit-III: include 1 renewable energy measure and other passive/active \\
measures \\
\hline COMB09 & 28.9 & 56.0 & 84.9 & 13.6 \\
\hline COMB10 & 54.7 & 58.1 & 112.8 & 19.6 \\
\hline COMB11 & 52.4 & 60.0 & 112.4 & 15.9 \\
\hline COMB12 & 37.4 & 59.2 & 96.6 & 13.6 \\
\hline Extensive Retrofit: include 2 renewable energy measures and other passive/active measures \\
\hline COMB13
\end{tabular}



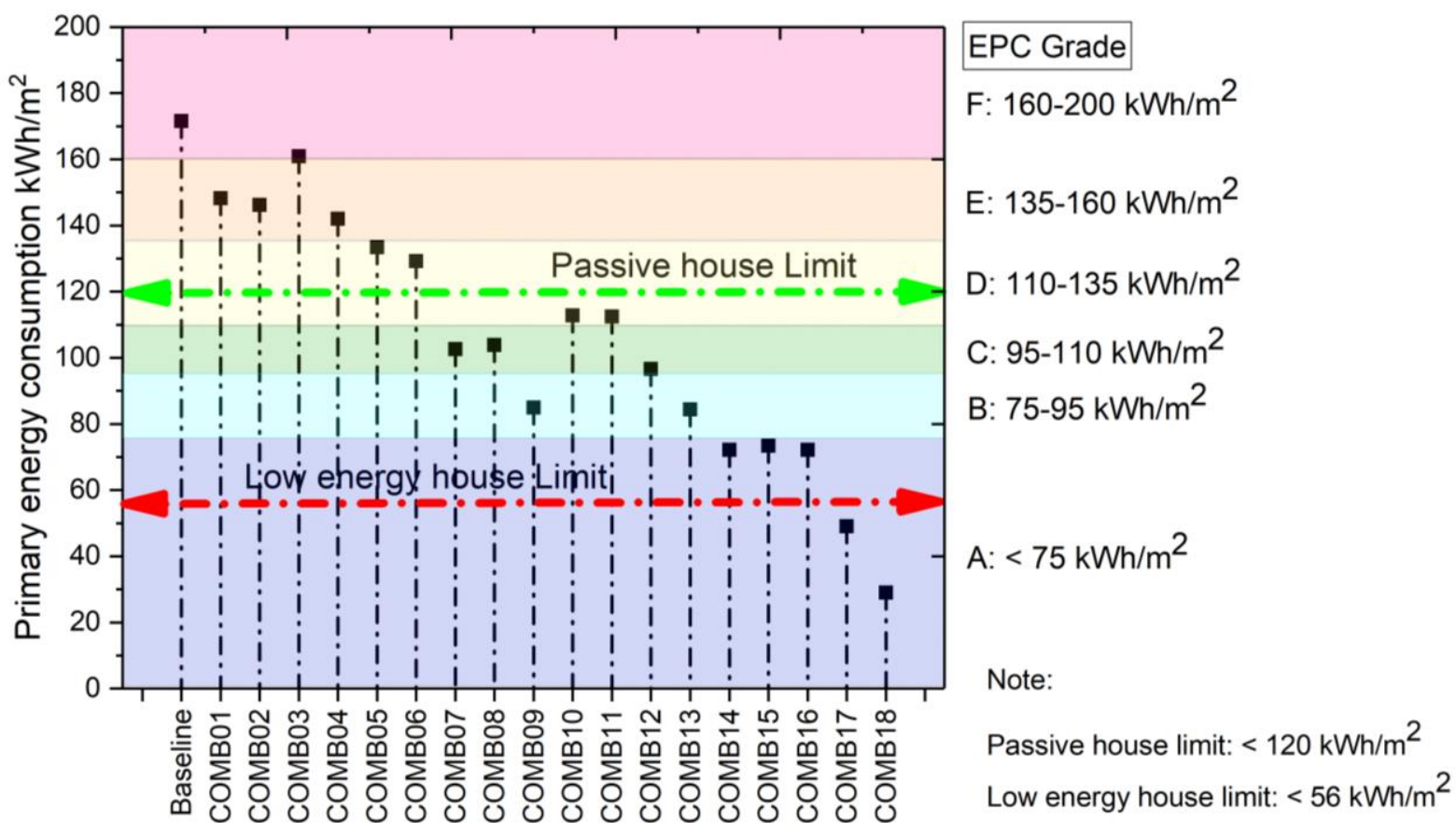

394

Fig. 7 The relationships between primary energy consumption and (EPC) for the 18 retrofit combination packages

\subsection{EPC related retrofit approach}

As described in section 2.3, a novel EPC related holistic retrofit approach featuring a novel assessment factor (ELD) has been applied in this research with the aim to reduce the amount of simulation time involved in conventional retrofit approaches. The novel assessment factor Energy Limiting Difference (ELD), is defined as the difference between the maximum and minimum monthly net energy consumption, which can be obtained from the energy consumption in the coldest winter month and hottest summer month respectively.

In order to verify this approach, 3 groups of combination packages (COMB05\&08, COMB11\&12, COMB13\&15) have been chosen with their monthly thermal, electricity consumptions and renewable energy generations plotted in Fig. 8-10.

It can be found that, in general, all the combination packages show the same trend, with the maximum and minimum electricity, thermal energy consumption and the available renewable energy occurred in the coldest (January) and hottest (June) month respectively. This further 
410 demonstrates the possibility to conduct the energy consumption simulations for two months

411 (the coldest and hottest) and obtain the ELD assessment factor, which will then linked with

412 EPC grades.

413 As shown in Fig. 8, with ELD of $11.5 \mathrm{kWh} / \mathrm{m}^{2} \cdot \mathrm{mon}$, COMB05 is classified as EPC grade

414 D. While COMB 08 fits into EPC grade C, with reduced ELD value of $8.25 \mathrm{kWh} / \mathrm{m}^{2} \cdot$ mon.

415 Similar EPC upgrading can also be observed in Fig. 9 which shows the retrofit simulation

416 results with combinations of HR and GSHP in COMB11, and combinations of GR, HR and

417 GSHP in COMB12. With ELD of $11.42 \mathrm{kWh} / \mathrm{m}^{2} \cdot \mathrm{mon}, \mathrm{COMB} 11$ can be categorized as EPC

418 grade D. While COMB 12 fits into EPC grade C, with reduced ELD value of $8.91 \mathrm{kWh} / \mathrm{m}^{2}$. 419 mon.

420 Furthermore, by comparing COMB12 (Fig. 9) and COMB13 (Fig. 10), one additional ERM 421 (ST) has been included in COMB 13 in comparisons with the existing ERMs in COMB 12 (GR, 422 HR and GSHP). Without changing the building thermal behaviour, COMB13 utilizes the on423 site generated renewable thermal energy, which enables its EPC upgrading to grade B 424 compared with grade $\mathrm{C}$ in COMB12. As noticed, the overall ELD in COMB12 of 425 $8.91 \mathrm{kWh} / \mathrm{m}^{2} \cdot$ mon will be reduced to $5.93 \mathrm{kWh} / \mathrm{m}^{2} \cdot$ mon in COMB13, with $33.4 \%$ of 426 primary energy saving in the coldest month. Therefore, installation of ST plays crucial roles in 427 upgrading EPC from Grade C to B.

428 By replacing ST in COMB13 with BIPV in COMB15, it would be interesting to investigate the 429 EPC upgrading potential by switching the solar thermal energy into solar electric energy. As 430 shown in Fig. 12, COMB15 will be upgraded to EPC grade A comparing with EPC grade B 431 for COMB13. Analysing the ELD difference, it is easy to find that the overall ELD $432\left(5.93 \mathrm{kWh} / \mathrm{m}^{2} \cdot \mathrm{mon}\right)$ in COMB13 will be reduced to $5.79 \mathrm{kWh} / \mathrm{m}^{2} \cdot \mathrm{mon}$ in COMB15, 433 with $2.3 \%$ of primary energy saving in the coldest month. Therefore, it could be concluded that 

for EPC upgrading in comparison with solar thermal energy.

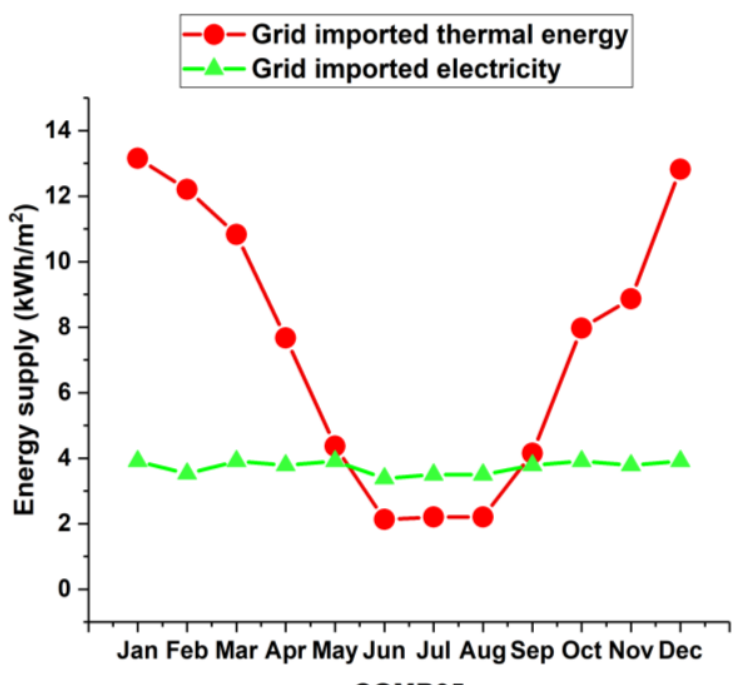

COMB05

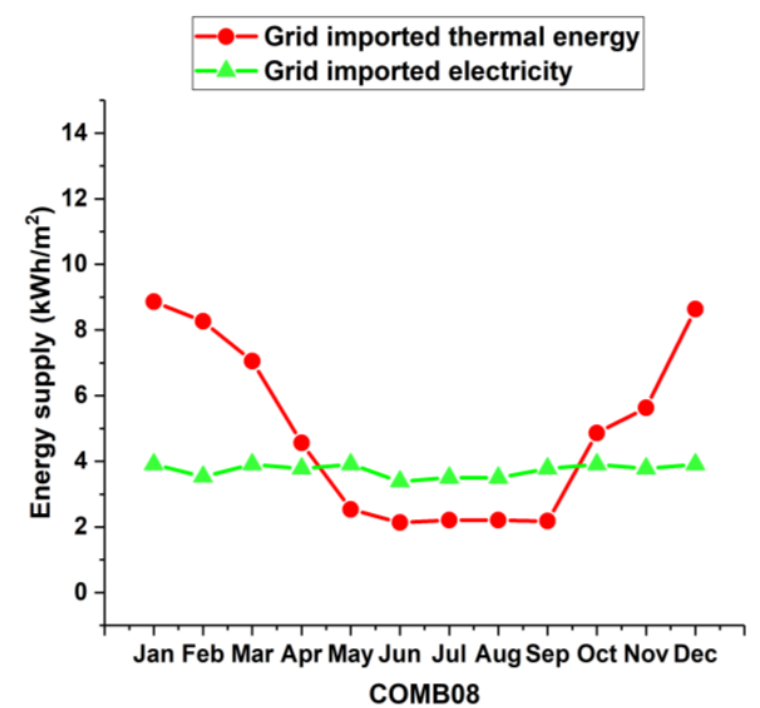

сомв08

Fig. 8 Monthly analysis of EPC upgrading from D (COMB05) to C (COMB08)
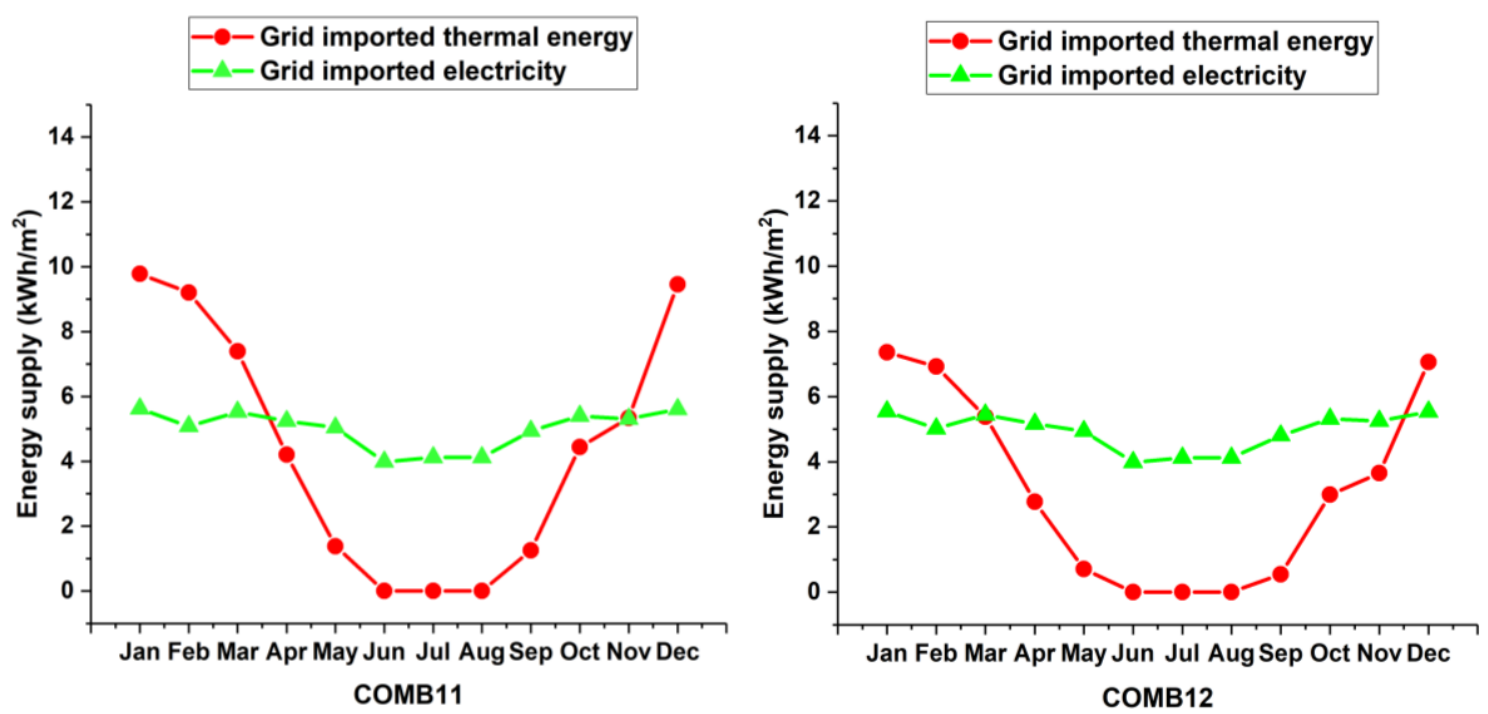
COMB11

$$
\text { СOMB12 }
$$

Fig. 9 Monthly analysis of EPC upgrading from D (COMB11) to C (COMB12) 


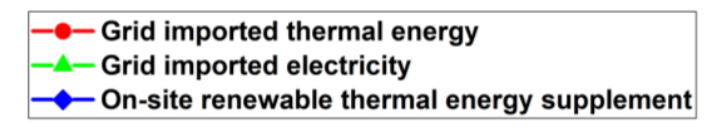

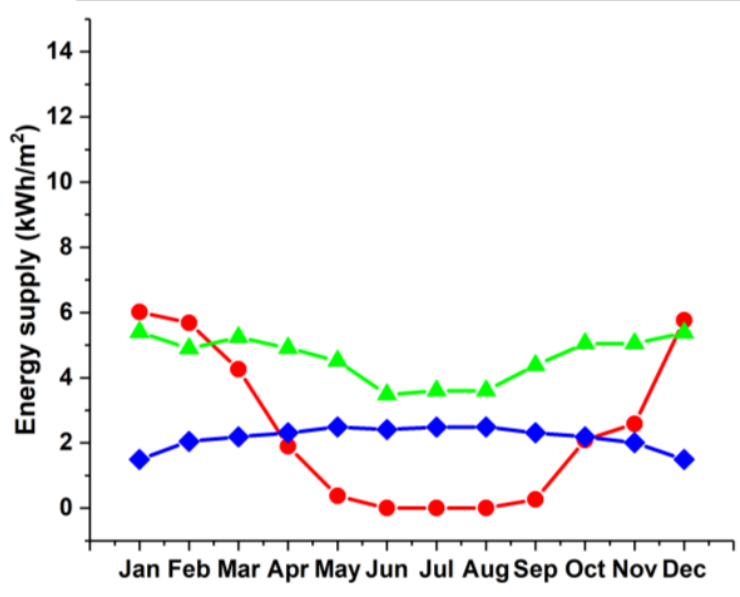

СомB13

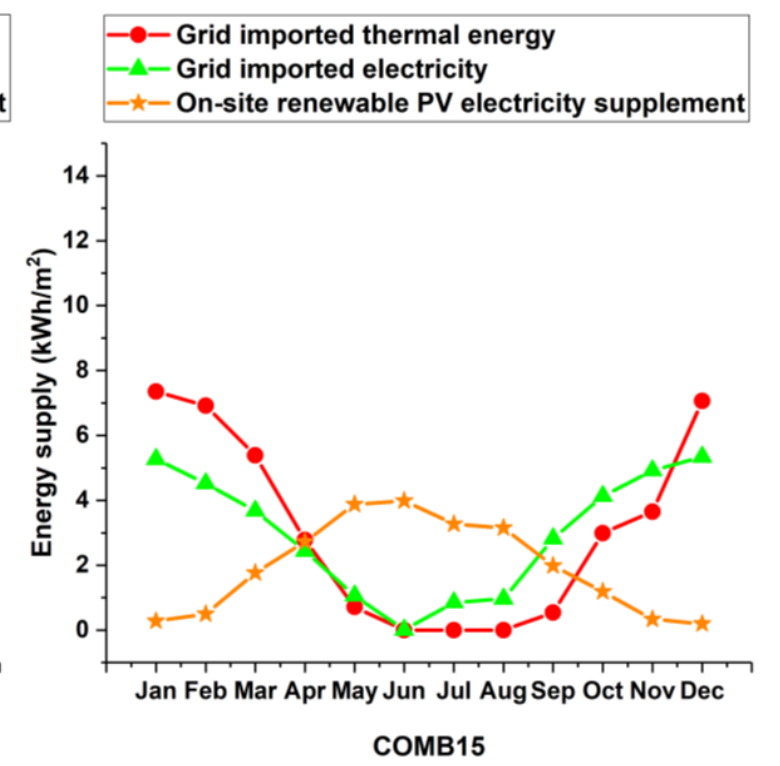

COMB15

Fig. 10 Monthly analysis of EPC upgrading from B (COMB13) to A (COMB15)

442 Additionally, the conventional approach which needs to perform the 12-month energy consumption simulations for a typical year requires 190 seconds simulation time. Compare with that, this ELD-EPC related approach only needs to calculate the maximum and minimum energy consumptions and available renewable energy in two months (the hottest and coldest) during one year period, with significantly reduced simulation time of only 42 seconds.

447 Therefore, the ELD assessment factor can be considered as a unique indicator to identify the EPC grades, which significantly facilitates the retrofit decision-making process with reduced simulation times.

Appling the EPC grades (shown in Fig. 7) from the conventional approach into the ELD assessment factor (shown in Fig.11) identified from this novel approach, a range of ELD values have been linked with the relevant EPC grades for the proposed COMBs, as shown in Table 8. All the combination packages with ELD values more than $11.42 \mathrm{kWh} / \mathrm{m}^{2} \cdot$ month cannot match with the EPC C grade, indicating a further need for deep retrofiting. The most recommended COMBs which better facilitate the EPC upgrading are also summarized in Table

8. For this specific research, the baseline ELD assessment factor is $18.06 \mathrm{kWh} / \mathrm{m}^{2} \cdot \mathrm{month}$, which falls into EPC grade F. With recommendation of GR based passive retrofit combinations, 
458 the ELD values in the range of 13.58 to $14.02 \mathrm{kWh} / \mathrm{m}^{2} \cdot$ month indicating EPC grade E. With 459 recommendation of 'GR + HR', the ELD in the range of 11.42 to $12.65 \mathrm{kWh} / \mathrm{m}^{2} \cdot$ month 460 indicates EPC grade D. EPC grade C is matching with ELD in the range of 8.25 to 9.49 $461 \mathrm{kWh} / \mathrm{m}^{2} \cdot$ month, with typical retrofit recommendation of 'GR + HR + GSHP'. Besides, the 462 indication of EPC grade B correlated to ELD value in the range of 8.25 to $9.49 \mathrm{kWh} / \mathrm{m}^{2}$. 463 month, with typical retrofit recommendation of 'GR + AT + SP + GSHP'. Finally, the EPC 464 grade A requires the ELD within -0.42 to $5.79 \mathrm{kWh} / \mathrm{m}^{2} \cdot$ month, with retrofit 465 recommendation of 'GR + SP + GSHP' + BIPV' combination.

466

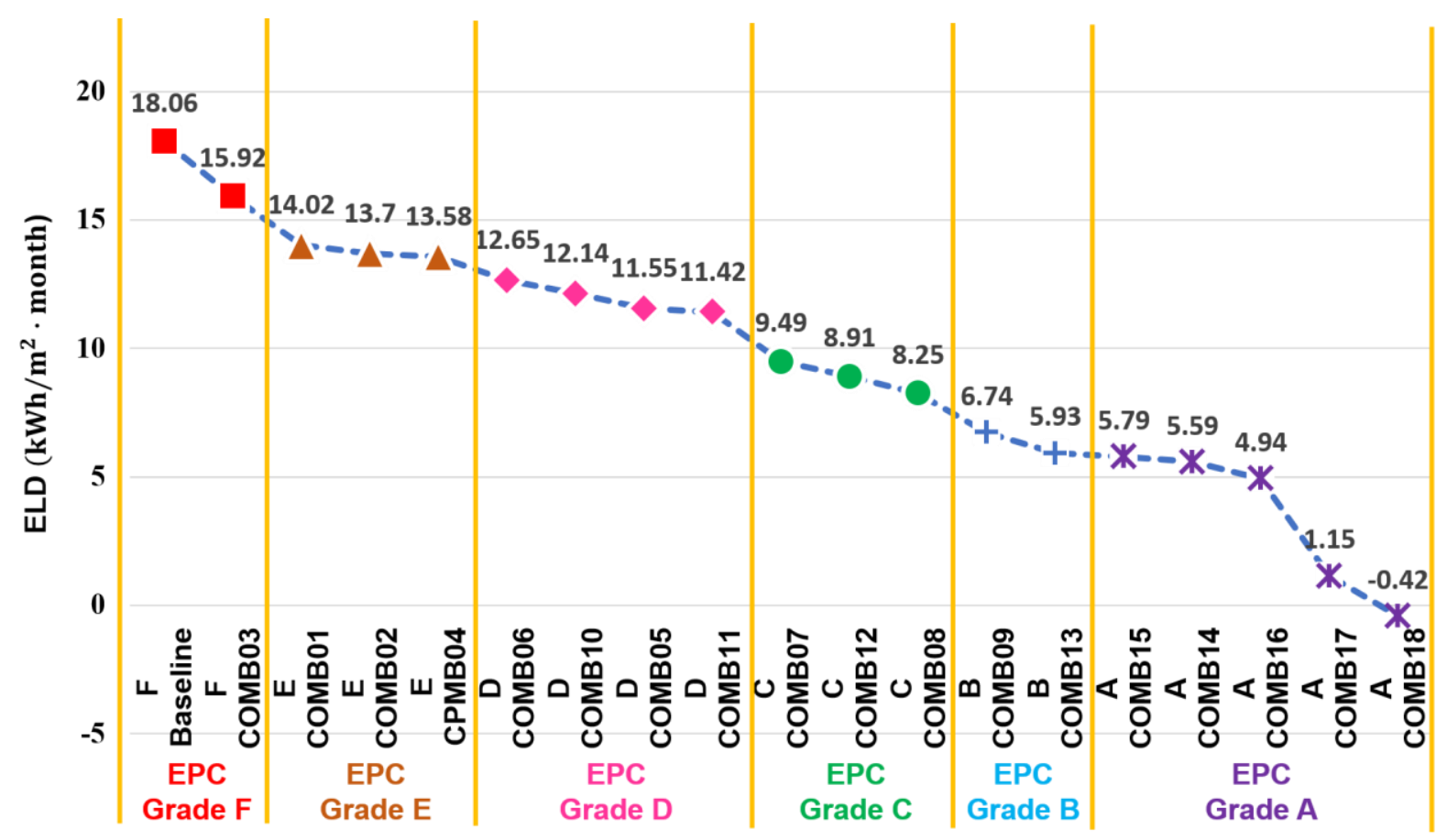

Fig. 11 The relationship between EPC grades and ELD assessment factors Table 8 EPC upgrade indication with ELD ranges and retrofit recommendations

\begin{tabular}{|c|c|c|c|}
\hline EPC grade & $\begin{array}{c}\text { ELD ranges } \\
\left(k W h / m^{2} \cdot\right.\end{array}$ & $\begin{array}{c}\text { Annual Primary } \\
\text { energy consumption }\end{array}$ & Recommended ERMs \\
& $m o n t h)$ & $\left(k W h / m^{2}\right)$ & \\
\hline $\mathrm{F}$ & $15.92-18.06$ & $160-200$ & GR \\
\hline $\mathrm{E}$ & $13.58-14.02$ & $135-160$ & \\
\hline
\end{tabular}




\begin{tabular}{|c|c|c|c|}
\hline D & $11.42-12.65$ & $110-135$ & GR + HR \\
\hline C (minimum & $8.25-9.49$ & $95-110$ & GR + HR + GSHP \\
\hline B & & & \\
\hline A & $-0.42-5.79$ & $56-75$ & GR + HR + GSHP + BIPV \\
\hline Low energy house & $-0.42-1.15$ & $<56$ & GR + AT + HR + SP + \\
(Tor Helge Dokka, & & & GSHP +BIPV \\
2013) & & & \\
\hline
\end{tabular}

\section{Conclusion}

471 This paper presents a novel holistic EPC related retrofit approach which links the possible

472 combination packages with their post retrofit EPC grades. This approach is based on the ELD 473 assessment factors, thereby facilitating the rapid yet accurate retrofit decision-making process. 474 A low-rise apartment block in Oslo was chosen as the demo site building. Employing the 475 simulation engine of IES VE software with the weather data acquired from Energy Plus, a novel simulation methodology was adopted: i) After analysing existing baseline building features and environmental conditions, eleven passive, active and renewable energy retrofit measures (ERMs) with specific technical parameters were firstly determined. ii) Based on the 479 three principle of "Fabric priority", "Renewable in supplement", and "Avoid complicated installation operation', these ERMs were then combined into 18 combination packages, which were categorized into four levels: "Moderate Retrofit-I, II, III" and "Extensive Retrofit" according to EU policy paper (Artola, 2016). A translation from the EPC standards to a user483 friendly assessment factor (ELD) and corresponding energy saving ranges for the proposed 484 COMBs are concluded, with the following conclusions drawn from this research:

1) Retrofit combination level 'Moderate Retrofit-I' (only passive measures) indicates the 
potential energy saving range of $6 \%$ to $17 \%$, which do not satisfy the minimum grade $\mathrm{C}$ of EPC requirements.

488

489

490

491

492

493

494

495

496

497

498

499

500

501

502

503

504

505

506

507

508

509

510

2) Retrofit combination level 'Moderate Retrofit- II' (passive measures + active measures) represents the potential energy saving range of $22 \%$ to $40 \%$, with part of the COMBs satisfying the minimum grade $\mathrm{C}$ of $\mathrm{EPC}$ requirements.

3) Retrofit combination level 'Moderate Retrofit- III' (passive measures + active measures + GSHP) indicates the potential energy saving range of $34 \%$ to $51 \%$, with the proposed COMBs satisfying the EPC grade C and B.

4) Retrofit combination level 'Extensive Retrofit' indicates the potential energy saving range of $51 \%$ to $83 \%$, with all the COMBs satisfying the EPC grade B and most of the COMBs reaching EPC grade A.

This research showcases a novel rapid and user-friendly EPC upgrading assessment approach with a range of defined ELD assessment factors. Different from the conventional timeconsuming approaches that need to simulate the annual total energy consumptions, the proposed approach in this research simplifies such process by only considering the maximum and minimum primary energy consumption and available renewable energy in two extreme months (coldest and hottest). The case study in Oslo further helps to verify the feasibility of this ELD-based EPC assessment approach, which draws a relationship between the ELD assessment factor and the relevant EPC grades. Such approach provides a theoretical support that can greatly facilitate the rapid retrofit design and decision-making process in the future. By applying ELD-based EPC approach for the selection of ERMs, it could be concluded that among the two available solar energy resources, solar electric energy plays more important role for EPC upgrading in comparisons with solar thermal energy.

Finally, considering the number of ERMs incorporated, three COMBs with a maximum number of four ERMs are recommended for Oslo retrofit project, including: COMB12 - 
511 'GR+HR+GSHP' (reduction of 44\% primary energy consumption and 53\% carbon emission,),

512 COMB09 - 'GR+AT+SP+GSHP' (reduction of 51\% primary energy consumption and $60 \%$

513 carbon emission), and COMB15 - 'GR+HR+GSHP+BIPV' (reduction of 57\% primary energy

514 consumption and $60 \%$ carbon emission). By applying these 3 COMBs, the post-retrofit energy

515 performance will match with EPC grade of $\mathrm{C}, \mathrm{B}$ and $\mathrm{A}$ respectively, which provide a wide

516 range of possible solutions for the decision makers using such EPC related retrofit approach.

517 This novel holistic EPC related approach will serve as a useful guidance for similar retrofit

518 projects incorporating renewable energy measures in Oslo district and other high-density area

519 in cold climate region.

520 This paper focuses on the ELD-based EPC assessment approach for retrofit decision-making process in cold climate area. However, in other climate Zone, the results might be dependent on climatic conditions as well as the existing building fabric and service system conditions. Therefore, future work will be concentrated on further validation of such ELD-based EPC assessment approach in a diverse range of climate conditions.

\section{Acknowledgement}

527

The authors would like to acknowledge the financial support and contributions from European partners participations.

\section{References}

Artola, I. (2016). Boosting Building Renovation: What Potential and Value for Europe? : Study: European Parliament.

Ascione, F., Bianco, N., De Stasio, C., Mauro, G. M., \& Vanoli, G. P. (2017). Artificial neural networks to predict energy performance and retrofit scenarios for any member of a building category: A novel approach. Energy, 118, 999-1017. doi:https://doi.org/10.1016/j.energy.2016.10.126

Balaras, C. A., Dascalaki, E. G., Droutsa, K. G., \& Kontoyiannidis, S. (2016). Empirical assessment of calculated and actual heating energy use in Hellenic residential buildings. Applied Energy, 164, 115-132. doi:https://doi.org/10.1016/i.apenergy.2015.11.027

Balcombe, P., Rigby, D., \& Azapagic, A. (2013). Motivations and barriers associated with adopting 
microgeneration energy technologies in the UK. Renewable and Sustainable Energy Reviews, 22, 655666. doi:https://doi.org/10.1016/j.rser.2013.02.012

Baumhof, R., Decker, T., Röder, H., \& Menrad, K. (2018). Which factors determine the extent of house owners' energy-related refurbishment projects? A Motivation-Opportunity-Ability Approach. Sustainable Cities and Society, 36, 33-41. doi:https://doi.org/10.1016/i.scs.2017.09.025

Belpoliti, V., Bizzarri, G., Boarin, P., Calzolari, M., \& Davoli, P. (2018). A parametric method to assess the energy performance of historical urban settlements. Evaluation of the current energy performance and simulation of retrofit strategies for an Italian case study. Journal of Cultural Heritage, 30, 155-167. doi:https://doi.org/10.1016/i.culher.2017.08.009

Berardi, U. (2018). Aerogel-enhanced systems for building energy retrofits: Insights from a case study. Energy and Buildings, 159, 370-381. doi:https://doi.org/10.1016/i.enbuild.2017.10.092

Biswas, K., Desjarlais, A., Smith, D., Letts, J., Yao, J., \& Jiang, T. (2018). Development and thermal performance verification of composite insulation boards containing foam-encapsulated vacuum insulation panels. Applied Energy, 228, 1159-1172. doi:https://doi.org/10.1016/j.apenergy.2018.06.136

Byggteknisk forskrift (TEK17). (2017). Veiledning om tekniske krav til byggverk.

Carlsson, M., Touchie, M., \& Richman, R. (2017). A Compartmentalization \& Ventilation System Retrofit Strategy for High-Rise Residential Buildings in Cold Climates. Energy Procedia, 132, 867-872. doi:https://doi.org/10.1016/i.egypro.2017.09.682

Cascio, E. L., Ma, Z., Borelli, D., \& Schenone, C. (2017). Residential Building Retrofit through Numerical Simulation: A Case Study. Energy Procedia, 111, 91-100. doi:https://doi.org/10.1016/i.egypro.2017.03.011

Casquero-Modrego, N., \& Goñi-Modrego, M. (2018). Energy Retrofit of an Existing Affordable Building Envelope in Spain, Case Study. Sustainable Cities and Society. doi:https://doi.org/10.1016/i.scs.2018.09.034

Charles, A., Maref, W., \& Ouellet-Plamondon, C. M. (2019). Case study of the upgrade of an existing office building for low energy consumption and low carbon emissions. Energy and Buildings, 183, 151-160. doi:https://doi.org/10.1016/i.enbuild.2018.10.008

Chen, X., Yang, H., \& Sun, K. (2016). A holistic passive design approach to optimize indoor environmental quality of a typical residential building in Hong Kong. Energy, 113, 267-281. doi:https://doi.org/10.1016/i.energy.2016.07.058

Collins, M., \& Curtis, J. (2018). Bunching of residential building energy performance certificates at threshold values. Applied Energy, 211, 662-676. doi:https://doi.org/10.1016/i.apenergy.2017.11.077

cooperatives, B. (May 2017). Mapping of maintenance, energy efficiency and the possibility of developments. Retrieved from

Criteria for passive houses and low-energy buildings - Residential buildings, NS3700 C.F.R. (2013).

Dahlhausen, M., Heidarinejad, M., \& Srebric, J. (2015). Building energy retrofits under capital constraints and greenhouse gas pricing scenarios. Energy and Buildings, 107, 407-416. doi:https://doi.org/10.1016/i.enbuild.2015.08.046

Davidson, R. (23rd March 2018). CHANGES TO EPC REGULATIONS - 1ST APRIL $2018 . \quad$ Retrieved from https://www.burnetts.co.uk/publications/blogs/changes-to-epc-regulations-1-april-2018

Desideri, U., Arcioni, L., Leonardi, D., Cesaretti, L., Perugini, P., Agabitini, E., \& Evangelisti, N. (2013). Design of a multipurpose "zero energy consumption" building according to European Directive 2010/31/EU: Architectural and technical plants solutions. Energy, 58, 157-167. doi:http://dx.doi.org/10.1016/i.energy.2013.02.063

Dodoo, A., Gustavsson, L., \& Tettey, U. Y. A. (2017). Final energy savings and cost-effectiveness of deep energy renovation of a multi-storey residential building. Energy, 135, 563-576. doi:https://doi.org/10.1016/i.energy.2017.06.123

Droutsa, K. G., Kontoyiannidis, S., Dascalaki, E. G., \& Balaras, C. A. (2016). Mapping the energy performance of hellenic residential buildings from EPC (energy performance certificate) data. Energy, 98, 284-295. doi:https://doi.org/10.1016/i.energy.2015.12.137

Engineers, T. C. I. o. B. S. (March 2015). Ventilation and air infiltrationCIBSE Guide A Environmental design (pp. 185-224): CIBSE.

Enongene, K. E., Murray, P., Holland, J., \& Abanda, F. H. (2017). Energy savings and economic benefits of transition towards efficient lighting in residential buildings in Cameroon. Renewable and Sustainable Energy Reviews, 78, 731-742. doi:https://doi.org/10.1016/i.rser.2017.04.068

Directive 2002/91/EC of the European Parliament on the Energy Performance of Buildings, (2002).

Directive 2010/31/EU of 19 May 2010 on the energy performance of buildings, (2010).

EUROPEAN COMMISSION. (2011). A Roadmap for moving to a competitive low carbon economy in 2050 EUROPEAN COMMISSION Retrieved from https://eur-lex.europa.eu/legal- 
Summary of the Impact Assessment accompanying the proposal for a recast of the EPBD, (2016).

Fan, Y., \& Xia, X. (2018). Building retrofit optimization models using notch test data considering energy performance certificate compliance. Applied Energy, 228, 2140-2152. doi:https://doi.org/10.1016/i.apenergy.2018.07.043

Francisco Pinto, J., \& Carrilho da Graça, G. (2018). Comparison between geothermal district heating and deep energy refurbishment of residential building districts. Sustainable Cities and Society, 38, 309-324. doi:https://doi.org/10.1016/j.scs.2018.01.008

Fregonara, E., Verso, V. R. M. L., Lisa, M., \& Callegari, G. (2017). Retrofit Scenarios and Economic Sustainability. A Case-study in the Italian Context. Energy Procedia, 111, 245-255. doi:https://doi.org/10.1016/i.egypro.2017.03.026

Global Climate Change Indicators. (2016). National Centers for Environmental Information, National Ocenic and Atomospheric Administation, USA.

Jradi, M., Lecuelle, P., Høj Madsen, K. M., Veje, C., \& Jørgensen, B. N. (2017). Dynamic Model-Driven Energy Retrofit of Bøgevangen and Runevej Daycare Centers in Aarhus. Energy Procedia, 132, 975-981. doi:https://doi.org/10.1016/j.egypro.2017.09.689

Jradi, M., Veje, C. T., \& Jørgensen, B. N. (2018). A dynamic energy performance-driven approach for assessment of buildings energy Renovation-Danish case studies. Energy and Buildings, 158, 62-76. doi:https://doi.org/10.1016/i.enbuild.2017.09.094

Knudsen diffusion. (August 2017). Retrieved from https://en.wikipedia.org/wiki/Knudsen diffusion

Kylili, A., \& Fokaides, P. A. (2015). European smart cities: The role of zero energy buildings. Sustainable Cities and Society, 15, 86-95. doi:https://doi.org/10.1016/i.scs.2014.12.003

Li, Y., Kubicki, S., Guerriero, A., \& Rezgui, Y. (2019). Review of building energy performance certification schemes towards future improvement. Renewable and Sustainable Energy Reviews, 113, 109244. doi:https://doi.org/10.1016/i.rser.2019.109244

Liu, Y., Liu, T., Ye, S., \& Liu, Y. (2018). Cost-benefit analysis for Energy Efficiency Retrofit of existing buildings: A case study in China. Journal of Cleaner Production, 177, 493-506. doi:https://doi.org/10.1016/i.jclepro.2017.12.225

Ma, Z., Cooper, P., Daly, D., \& Ledo, L. (2012). Existing building retrofits: Methodology and state-of-the-art. Energy and Buildings, 55, 889-902. doi:https://doi.org/10.1016/i.enbuild.2012.08.018

Martek, I., Hosseini, M. R., Shrestha, A., Edwards, D. J., Seaton, S., \& Costin, G. (2019). End-user engagement: The missing link of sustainability transition for Australian residential buildings. Journal of Cleaner Production, 224, 697-708. doi:https://doi.org/10.1016/j.jclepro.2019.03.277

Mauri, L., Vallati, A., \& Ocłoń, P. (2019). Low impact energy saving strategies for individual heating systems in a modern residential building: A case study in Rome. Journal of Cleaner Production, 214, 791-802. doi:https://doi.org/10.1016/i.jclepro.2018.12.320

Mazzarella, L. (2015). Energy retrofit of historic and existing buildings. The legislative and regulatory point of view. Energy and Buildings, 95, 23-31. doi:https://doi.org/10.1016/i.enbuild.2014.10.073

Menassa, C. C., \& Baer, B. (2014). A framework to assess the role of stakeholders in sustainable building retrofit decisions. Sustainable Cities and Society, 10, 207-221. doi:https://doi.org/10.1016/i.scs.2013.09.002

Mills, E., \& Rosenfeld, A. (1996). Consumer non-energy benefits as a motivation for making energy-efficiency improvements. Energy, 21(7), 707-720. doi:https://doi.org/10.1016/0360-5442(96)00005-9

Monzón, M., \& López-Mesa, B. (2018). Buildings performance indicators to prioritise multi-family housing renovations. Sustainable Cities and Society, 38, 109-122. doi:https://doi.org/10.1016/i.scs.2017.12.024

Mora, T. D., Cappelletti, F., Peron, F., Romagnoni, P., \& Bauman, F. (2015). Retrofit of an Historical Building toward NZEB. Energy Procedia, 78, 1359-1364. doi:https://doi.org/10.1016/i.egypro.2015.11.154

Niemelä, T., Kosonen, R., \& Jokisalo, J. (2017). Energy performance and environmental impact analysis of costoptimal renovation solutions of large panel apartment buildings in Finland. Sustainable Cities and Society, 32, 9-30. doi:https://doi.org/10.1016/j.scs.2017.02.017

Nord, N., Løve Nielsen, E. K., Kauko, H., \& Tereshchenko, T. (2018). Challenges and potentials for low-temperature district heating implementation in Norway. Energy, 151, 889-902. doi:https://doi.org/10.1016/j.energy.2018.03.094

Ó Broin, E., Mata, É., Göransson, A., \& Johnsson, F. (2013). The effect of improved efficiency on energy savings in EU-27 buildings. Energy, 57, 134-148. doi:https://doi.org/10.1016/i.energy.2013.01.016

OBOS Bastart. (2019). Retrieved from https://www.obos.no/

Paiho, S., Seppä, I. P., \& Jimenez, C. (2015). An energetic analysis of a multifunctional façade system for energy efficient retrofitting of residential buildings in cold climates of Finland and Russia. Sustainable Cities and 
Society, 15, 75-85. doi:https://doi.org/10.1016/j.scs.2014.12.005

Pascuas, R. P., Paoletti, G., \& Lollini, R. (2017). Impact and reliability of EPCs in the real estate market. Energy Procedia, 140, 102-114. doi:https://doi.org/10.1016/i.egypro.2017.11.127

Project, O.-M. (January 2013). Energy Efficiency Trends in the EU. Retrieved from http://www.odysseemure.eu/publications/

Psomas, T., Heiselberg, P., Duer, K., \& Bjørn, E. (2016). Overheating risk barriers to energy renovations of single family houses: Multicriteria analysis and assessment. Energy and Buildings, 117, 138-148. doi:https://doi.org/10.1016/i.enbuild.2016.02.031

Rabani, M., Madessa, H. B., \& Nord, N. (2017). A state-of-art review of retrofit interventions in buildings towards nearly zero energy level. Energy Procedia, 134, 317-326. doi:https://doi.org/10.1016/i.egypro.2017.09.534

REZBUILD Project. (2019). Retrieved from https://rezbuildproject.eu/

Serrano-Jimenez, A., Barrios-Padura, A., \& Molina-Huelva, M. (2017). Towards a feasible strategy in Mediterranean building renovation through a multidisciplinary approach. Sustainable Cities and Society, 32, 532-546. doi:https://doi.org/10.1016/i.scs.2017.05.002

Skaran, A. M. (2013). Typologies and energy demand modelling of the Norwegian building stock - Part 2 Apartment blocks built after 1980. (Project thesis), Norwegian University of Science and Technology (NTNU). (EPT-P-2013-107)

Standard 55-2013 -- Thermal Environmental Conditions for Human Occupancy. (2013). ANSI/ASHRAE.

Tadeu, S., Rodrigues, C., Tadeu, A., Freire, F., \& Simões, N. (2015). Energy retrofit of historic buildings: Environmental assessment of cost-optimal solutions. Journal of Building Engineering, 4, 167-176. doi:https://doi.org/10.1016/i.jobe.2015.09.009

Thullner, K. (2010). Low-energy buildings in Europe - Standards, Criteria and consequences. Retrieved from

Tor Helge Dokka, S. B. a. I. S. R. c. o. Z. E. B. Z. (2013). A Norwegian Zero Emission Building Definition. Passivhus Norden 2013, 188-201.

Webb, A. L. (2017). Energy retrofits in historic and traditional buildings: A review of problems and methods. $\begin{array}{lllll}\text { Renewable } \text { and Sustainable } & \text { 748-759. }\end{array}$ doi:https://doi.org/10.1016/i.rser.2017.01.145 